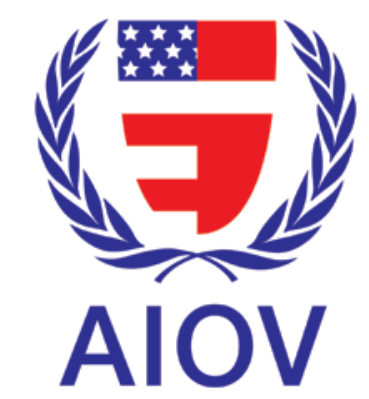

Americans in International

Organizations in Vienna

\title{
Americans in International Organizations in Vienna Workshop Summary Report
}

\author{
Donna Occhiogrosso \\ Consultant \\ Susan Pepper, Laura MacArthur, Tanya Collins \\ Brookhaven National Laboratory, Nonproliferation and National \\ Security Department
}

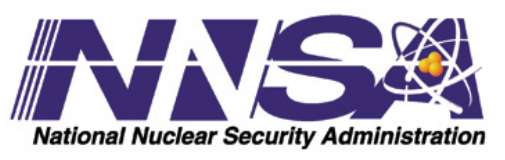

Notice: This manuscript has been authored by employees of Brookhaven Science Associates, LLC under Contract No. DEAC02-98CH10886 with the U.S. Department of Energy. The publisher by accepting the manuscript for publication acknowledges that the United States Government retains a non-exclusive, paid-up, irrevocable, world-wide license to publish or reproduce the published form of this manuscript, or allow others to do so, for United States Government purposes. 


\section{DISCLAIMER}

This report was prepared as an account of work sponsored by an agency of the United States Government. Neither the United States Government nor any agency thereof, nor any of their employees, nor any of their contractors, subcontractors, or their employees, makes any warranty, express or implied, or assumes any legal liability or responsibility for the accuracy, completeness, or any third party's use or the results of such use of any information, apparatus, product, or process disclosed, or represents that its use would not infringe privately owned rights. Reference herein to any specific commercial product, process, or service by trade name, trademark, manufacturer, or otherwise, does not necessarily constitute or imply its endorsement, recommendation, or favoring by the United States Government or any agency thereof or its contractors or subcontractors. The views and opinions of authors expressed herein do not necessarily state or reflect those of the United States Government or any agency thereof. 


\section{Table of Contents}

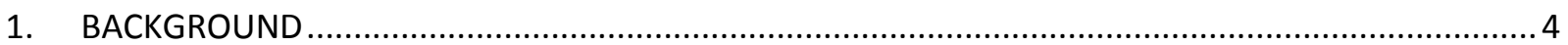

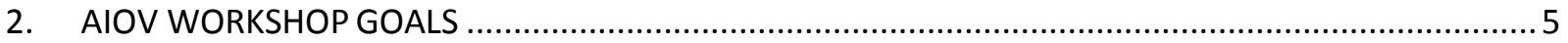

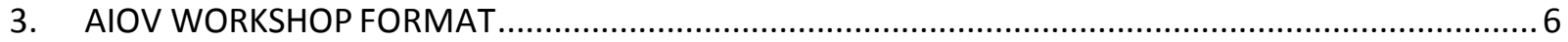

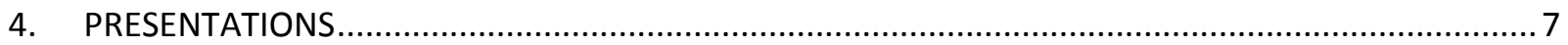

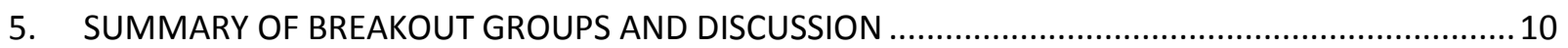

6. MAJOR OBSERVATIONS AND RECOMMENDATIONS …........................................................ 10

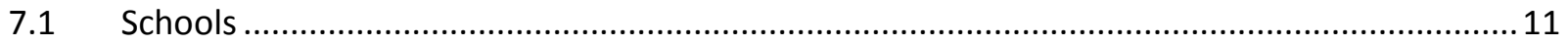

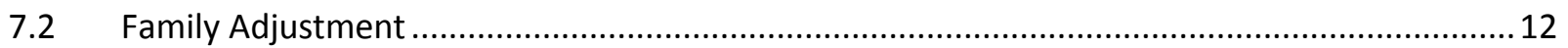

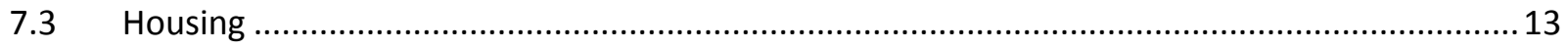

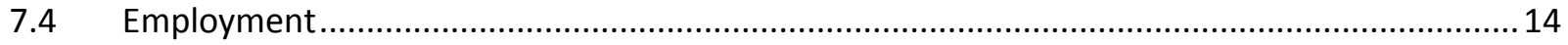

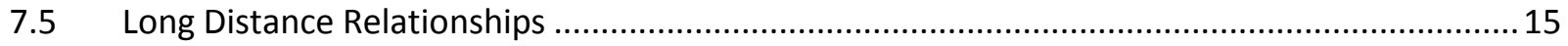

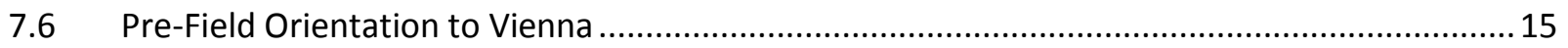

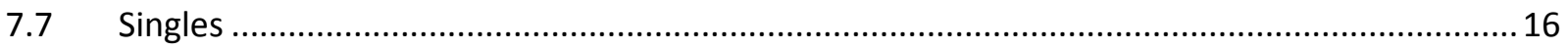

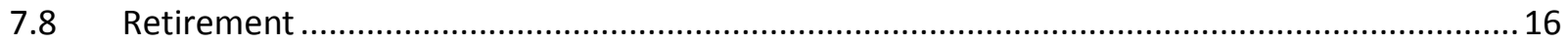

7.9 Shipping of Household Effects to and from Austria........................................................ 17

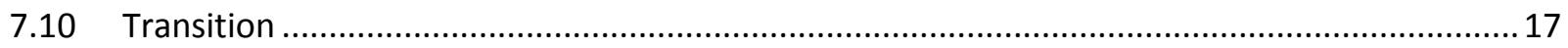

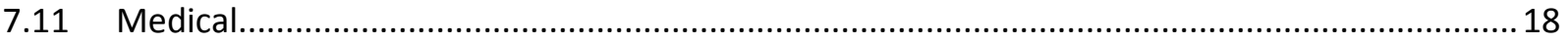

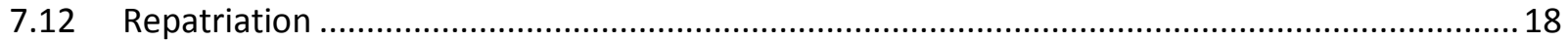

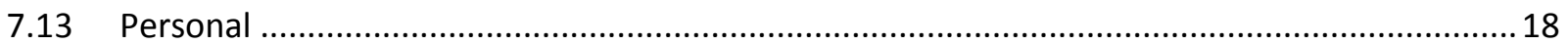

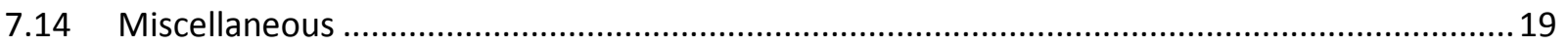

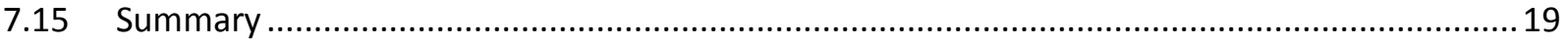

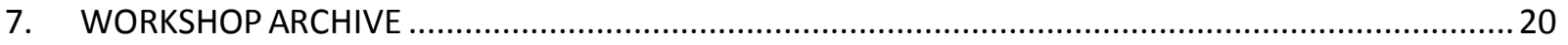

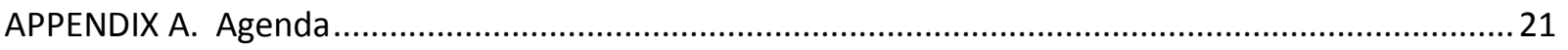

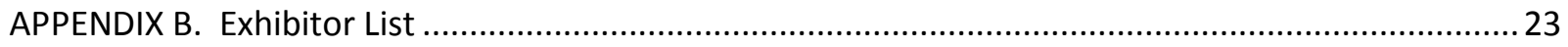

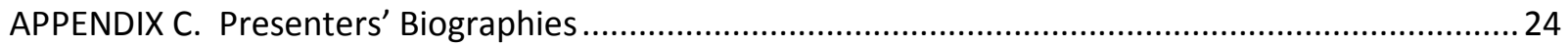

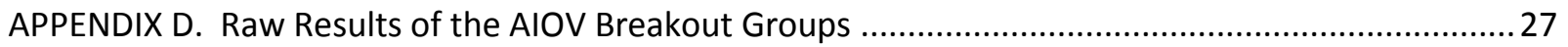

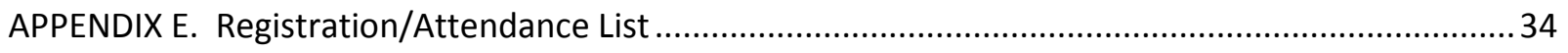

APPENDIX F. Dunbar Lockwood's Presentation, "DOE/NNSA Perspective: NGSI, Recruitment, and

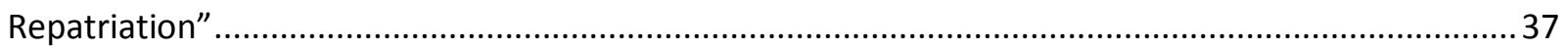




\section{INTRODUCTION}

The International Safeguards Project Office (ISPO) at Brookhaven National Laboratory (BNL), on behalf of the United States Department of Energy's (DOE) Next Generation Safeguards Initiative (NGSI) and the United States Support Program to International Atomic Energy Agency (IAEA) Safeguards (USSP), in collaboration with the Department of State (DOS) and Argonne National Laboratory (ANL), held a two-day workshop in Vienna, Austria, on October 3-4, 2011, at the NH Danube Hotel, for U.S. Citizens working in International Organizations (I/Os) in Vienna (AIOV).

The AIOV Workshop was intended to benefit U.S. citizens working in I/Os at the Vienna International Centre (VIC), by helping to improve dissemination of information to U.S. citizens preparing to arrive, live and work at I/Os in Vienna, as well as to U.S. citizens currently stationed there, with an emphasis on the IAEA Department of Safeguards. The AIOV Workshop addressed recommendations from the 2008 Enhanced Recruitment for International Safeguards (ERIS) Workshop, ${ }^{1}$ which was held to identify and consider ways to alleviate the obstacles to recruiting well-qualified U.S. citizens for positions in the IAEA Department of Safeguards.

The AIOV workshop brought together over 100 U.S. citizens working in I/Os to exchange ideas and to share knowledge, and to gather experts to help identify and recommend ways to enhance living and working experiences in Vienna.

\section{BACKGROUND}

In October 2008, the USSP and the NGSI sponsored a workshop on Enhanced Recruitment for International Safeguards (ERIS) at BNL, in Upton, New York. The objective of the ERIS workshop was to identify ways to mitigate or alleviate the obstacles to recruiting well-qualified U.S. citizens for positions in the IAEA Department of Safeguards. The ERIS Workshop resulted in a number of recommendations related to increasing awareness of the IAEA in the United States and to address the obstacles to recruiting well-qualified U.S. citizens for positions at the IAEA by:

- Providing newcomers a forum in which to network with knowledgeable and experienced U.S. citizens currently living and working in Vienna;

- Gathering information from current employees regarding challenges they have faced as U.S. citizens living and working in Vienna so that the United States can better focus the information provided to new arrivals;

\footnotetext{
${ }^{1}$ Pepper, S., M. Rosenthal, L. Fishbone, D. Occhiogrosso, C. Carroll, M. Dreicer, R. Wallace, and J. Fankhauser, Next Generation Safeguards Initiative Workshop on Enhanced Recruiting for International Safeguards, December 2008, ISPO Report \#543.
} 
- Obtaining information about living and working in Vienna that will enable improved outreach and public relations efforts to recruit U.S. citizens for in Vienna;

- $\quad$ Finding ways to mitigate the difficulties experienced by working couples by assisting domestic partners in identifying opportunities in Vienna, including employment and non-employment options; and

- Ensuring that family needs are being addressed.

The ERIS workshop recognized that human resources are a major asset in promoting the peaceful uses of nuclear technologies and that there are specific obstacles to recruiting U.S. citizens for positions at the IAEA. Foremost, it was recognized that there are difficulties in accepting a foreign assignment. American families often include two working professionals. In order to attract either of them, there have to be opportunities for both of them. The ERIS workshop participants recommended that the U.S. government address issues facing spouses and other partners who relocate to Vienna with IAEA recruits. The AIOV workshop was developed to address the issue of spousal employment and the family's well-being as contributing factors to the overall success of the employee's international appointment.

\section{AIOV WORKSHOP GOALS}

The United States encourages its citizens to apply for professional positions at I/Os, and the DOS assists U.S. citizens interested in overseas employment opportunities, making every effort to promote appropriate U.S. representation in the Department of Safeguards.

NGSI and the USSP have responsibilities related to recruitment for the IAEA Department of Safeguards. ANL recruits for other departments of the IAEA and the State Department recruits for all I/Os. While the multiple sponsors of the workshop had somewhat different interests, the workshop organizers welcomed participants from all I/Os in Vienna based on the understanding that the experiences of U.S. citizens working at the various organizations in Vienna are similar and they can help one another. Nearly 100 attendees from the IAEA (including spouses/partners) participated, of which about half were from the Department of Safeguards. Realizing that there are many difficulties in accepting foreign assignments, such as spousal employment, cultural differences, communication struggles and separation from community support systems, the goal of the workshop was to bring U.S. citizens and their partners, who are directly affected by these issues, together with experts who can recommend ways to enhance living and working experiences in Vienna. The feedback from this workshop will help to improve U.S. recruitment programs for the IAEA and other I/Os in Vienna and better assist future candidates. 


\section{AIOV WORKSHOP FORMAT}

The focus of this workshop was on issues that affect recent I/O hires and family members. The two days provided attendees with opportunities to network, meet other Americans and learn about opportunities for finding employment, improving qualifications, or identifying other activities to meaningfully occupy time spent living in Vienna. In addition, the agenda (Appendix A) covered topics that would help newcomers adapt more quickly to Vienna and their new jobs. The workshop started on October 3, 2012, with several representatives of the U.S. government and the IAEA speaking about their roles and interests in recruitment and staffing. Additional presentations by representatives of the Foreign Service Institute (FSI), the Vienna Expat Center, and the law firm of Dorda, Brugger, Jordis addressed services available to U.S citizens in Vienna. Michael Gates, of Richard Lewis Communications, delivered an extended presentation on the challenges of crossing cultures. The day ended with a wrap up session that summarized the day's presentations and prepared the participants for the second day.

On the evening of October 3rd, attendees continued to interact at a reception and social gathering held at the residence of U.S. Ambassador to International Organizations in Vienna (UNVIE), Glyn Davies.

October 4th began with two scheduled speakers: David Panakkal, of the U.S. Embassy, spoke about career shock and the effects of living and working overseas, and Lydia Goutas, of Lehner Executive Associates, spoke about career adjustment. Afterwards three breakout groups were formed and facilitated discussions were held for two hours. After the breakout groups concluded, there were presentations from representatives from the U.S. Consulate on services it offers to U.S. citizens abroad and from the U.S. Embassy's Regional Security Office on safety overseas. During these presentations, the breakout group facilitators and the note-takers met to prepare a summary of the results from each group's findings. The summary was delivered, and the workshop was adjourned.

Informal lunches and refreshment breaks provided opportunities for attendees to meet each other, to build networks and to visit with exhibiting vendors. The workshop coordinators invited a range of organizations to distribute helpful information to the attendees. The American Women's Association (AWA), the Women's Career Network (WCN), and the United Nations Women's Guild (UNWG) provided information to women regarding the different types of support groups available in Vienna and the importance of joining these groups as a way to become connected with the community. Other exhibitors included Webster University, for adults seeking educational opportunities, and the International Christian School, which provides instruction for children. Both schools offer an English speaking environment. The City of Vienna's MA-35 Immigration and Residency and the law firm of Dorda, Brugger, Jordis were 
available to assist individuals with situations regarding their legal status in Vienna. The Vienna Expat Center provided information on the Austrian red-white-red card for people seeking employment in Vienna. Some vendor representatives were also speakers.

Presentations are summarized in Section 5. Findings are summarized in Sections 6 and 7 and Appendix D. A list of exhibitors and their contact information can be found in Appendix B.

\section{PRESENTATIONS}

The workshop consisted of 13 presentations scheduled over two days. The series of presentations was designed to orient participants as to the purpose of the workshop, to define the roles of each government organization involved, and to provide information regarding services available to ease the transition for and support Americans living and working in Vienna, Austria. The presentations are summarized below. A short biography of each presenter is provided in Appendix C. A complete copy of each presentation is provided online in the workshop archive (see Section 8).

\section{U.S. Mission Objective}

Ambassador Glyn Davies spoke about the importance of civil servants, the happiness of the spouse/partner during the overseas assignment, the need for this type of workshop, and how the U.S. government would like for this outreach to continue.

\section{Workshop Objectives}

Susan Pepper explained the objectives of the workshop. The workshop was organized to assist U.S. citizens who are living in Vienna and working in Vienna-based I/Os by identifying ways to coordinate and disseminate information between the responsible agencies and to discuss opportunities for and expectations of the employees and their domestic partners. Ms. Pepper provided a brief overview of the workshop presentations and format in relation to this goal.

\section{DOE Perspective}

Dunbar Lockwood - The main sponsor of the workshop was the DOE/NNSA Next Generation Safeguards Initiative (NGSI). Mr. Lockwood discussed NGSI, its Human Capital Development (HCD) component, and how it is designed to serve the United States, the IAEA, and the international community. One of the goals of the HCD program is to attract, recruit, educate, and train individuals for the IAEA Department of Safeguards. Mr. Lockwood noted that approximately $80 \%$ of U.S. Safeguards experts in the U.S. national laboratories are projected to retire in the next 15 years; this makes it essential to maintain a pool of well-qualified candidates to fill IAEA vacancies as they arise. To underscore NGSI's role in recruitment and repatriation, Mr. Lockwood cited that there are currently eight IAEA employees who previously worked on NGSI projects at U.S. laboratories and sixteen former IAEA employees now contributing to NGSI in the United States to underscore NGSI's role in recruitment and repatriation. 


\section{DOS and $\mathrm{I} / \mathrm{O}$ Role}

Christopher Klemm discussed the role of the Department of State (DOS) in relation to the Vienna-based I/Os. The DOS provides funding to support a variety of IAEA programs. DOS promotes U.S. representation in I/Os by advertising vacancies and providing guidance and support to applicants. Mr. Klemm said that this workshop is a test case which can lead to other workshops for U.S. citizens in other international locations.

\section{IAEA Recruitment}

Catherine Monzel gave an overall presentation about IAEA recruitment practices. Assistance available for newcomers includes support with relocation (to and from Vienna), orientation, training, language courses, tax preparation, and housing. Ms. Monzel spoke about what to include on a Personal History Form (PHF) so that the PHF can be accurately assessed by the IAEA's online filtering system. Opportunities for the spouse/partner exist as Professional (P) staff, General (G) staff, local hires, and temporary assignments. The IAEA maintains a roster for temporary assignments which can be very diverse. The spouse/partner may apply for a job at the IAEA as long as the position is not in the same line of authority as that of the appointee and she/he is well-qualified. It was noted that the PHF should reflect international experience and language abilities. Currently, the U.S. has the largest representation in the IAEA with 200 people on staff; among the professional staff of who are U.S. citizens, $24 \%$ are women.

\section{Foreign Service Institute}

Christopher Hoh provided insight as to the service of the FSI and the training that could be offered to U.S. Citizens in UN Agencies. He spoke about distance learning - before and after arrival that can include topics related to work, leadership skills, moving overseas, orientation and language. Courses can be taken by the entire family and can be targeted to different age groups. Visit http://fsitraining.state.gov for a course listing and course schedules. People working in $\mathrm{I}$ Os are eligible to take these courses.

\section{Vienna Expat Center Services}

Friedrich Bruckner explained the role of the Vienna Expat Center and its services. All services are free of charge and can be provided privately. The Center is supported by the Austrian Government for the international community. It hosts activities and events for the AWA and the WCN, and holds income tax, social security, and employment workshops. The Center will assist people in seeking groups with similar interests and will help with communication and translation. Mr. Bruchner informed the audience of the new Austrian law and the associated $\mathrm{red} / \mathrm{white} / \mathrm{red}$ card that improves employment opportunities for non-European Union citizens.

\section{Immigration Topics}

Elmar Drabek of the law firm of Dorda, Brugger, Jordis spoke about work permits, legitimization for the unmarried partner, and retiring in Vienna, and offered services to anyone needing assistance with legal matters in Vienna. His law firm can help individuals and their family members obtain visas. The firm has extensive expertise and success in these areas. 


\section{Crossing Cultures}

Michael Gates gave a two-hour training lecture on multicultural workplaces, and provided insight to the Austrian culture. He provided perspective and insight on cultural differences among the distinct language groups of the IAEA, which are French, English, Russian, Arabic, Chinese, and Spanish. His lecture incorporated audience interaction and collective examples. Mr. Gates emphasized that effective communication is based on listening and understanding your own style.

\section{Career Shock}

David Panakkal addressed the transition to living and working abroad and its effect on the family. This includes financial considerations associated with a foreign work assignment, such as salary, relocation, children's education, and training. The spouse's adjustment is a very important determinant of the family's overall adjustment to the overseas move. Mr. Panakkal spoke about the culture shock of a foreign environment and the awareness of career shock. He identified the physical symptoms of stress and recommended techniques for coping in a foreign environment.

\section{Career Adjusting}

Lydia J. Goutas offered her expertise and knowledge regarding career adjustment for the spouse/partner. She presented tools and techniques for reinventing one's self, reassessing goals and directions, and finding a job in Vienna. Flexibility and a willingness to travel are advantages. She explained the differences between resumes and CVs; the resume is brief, whereas the CV can be longer. CVs are used more widely in Europe than in the United States. Ms. Goutas stressed the importance of joining groups for networking and noted that Vienna has a wonderful support system for women. Hilary Warmoth, a career coach, is available to assist with workshops, job restructuring, and the preparation of a two-minute "elevator speech" to sell one's self to a company. Ms. Warmoth can be contacted at hnwarmoth@yahoo.co.uk. Ms. Goutas drew the audience's attention to ISPO's Opportunities for Americans in Vienna ${ }^{2}$ brochure, which identifies opportunities for employment.

\section{American Consulate Services}

Catherine Muller explained the services of the American Consulate including notary services, absentee voting, and registering newborn children. She specified the benefit of registering with the U.S. Embassy while living in Vienna. Visit http://austria.usembassy.gov/service.html.

\section{Safety Abroad}

Mary Jo Swinimer's presentation revolved around the topic of safety abroad; she addressed the importance of being aware of one's surroundings and new laws, being able to contact emergency services when in need of an ambulance or to report a fire or an accident, registering with the U.S. alert system, ${ }^{3}$ and the requirements for driving in Vienna. She told the audience

${ }^{2}$ http://www.bnl.gov/ispo/recruitment/brochures.asp

${ }^{3}$ go to https://step.state.gov/step 
that it is important to obtain apartment insurance to cover any loss or damage to the contents of the home.

\section{SUMMARY OF BREAKOUT GROUPS AND DISCUSSION}

The break-out sessions began on October 4th. The attendees formed three separate groups and were placed in three different rooms. The groups were formed based on traditional demographic models: married couples with children, married couples without children, and singles. Each group was assigned a facilitator and a note taker. The role of the facilitator was to guide the group into constructive discussion and to keep the discussion focused. The role of the note taker was to record the points mentioned and capture them for later presentation to all attendees. Each group addressed particular issues of interest such as seeking employment or other opportunities in Vienna, family needs, employment concerns, professional development, education, volunteering, and social activities, as the issues pertained to their group. It was noted that a fourth group for people in long-distance relationships should have been formed since there were many in that situation.

Prior to the end of the workshop, a representative from each group presented the group's conclusions. Appendix $D$ is a compilation of those findings. In the spirit of encouraging open discussion, no ideas were rejected.

In summary, the recommendations from each group revolved around having a support system, reviving the USSP's host family program, and having opportunities to meet regularly with other Americans, informally or socially. This input will be used by ISPO, ANL and U.S. government agencies to assist the Vienna-based I/O community.

\section{MAJOR OBSERVATIONS AND RECOMMENDATIONS}

The outcome of the workshop was very optimistic. Many participants were thankful and appreciative of the support from the U.S. government. Some testimonials received were:

"Thank you very much for the wonderful workshop. In the end, I was able to attend two sessions and it was very worthwhile. I hope that you will be able to launch the workshops in other UN cities, as well as in the States."

"Thank you again for organizing the seminar - the speakers were wonderful, and it was a great opportunity to meet and talk with other Americans. "

A representative from the U.S. Mission said, "The workshop was a terrific opportunity for Americans working at the Vienna International Centre to share their experiences and learn about resources." 
A promotional video was created based on participants' personal experiences about living and working overseas. ${ }^{4}$ Other foreign nationals at the VIC expressed strong interest in this type of workshop and stated the desire to have one for their country's citizens as well.

The breakout sessions resulted in numerous comments from the participants regarding their positive and negative experiences in Vienna and their suggestions for ways the USSP, the NGSI, and other related and supportive U.S. programs could help U.S. citizens living and working abroad at I/Os in Vienna. These comments and suggestions were presented to the workshop participants as a wrap up to the workshop. Following the meeting, the workshop organizer and ISPO analyzed the comments and suggestions, and placed them into categories. The raw results are provided in Appendix D. ${ }^{5}$ Each specific category is discussed in further detail in the following sub-sections along with some recommendations.

\subsection{Schools}

The IAEA and other I/Os reimburse parents for a percentage of the cost of private elementary and secondary education. While the working parent can begin a work assignment at any time during the year, the schools operate on a typical academic calendar and it can be difficult to place students mid-year. There are several schools with different focuses and objectives to choose from. There is a high demand for places in the international schools and sometimes there are waiting lists which will affect the parents' choice of schools. Sometimes siblings must be placed in different schools. The choice of school may affect where the family lives. Parents are concerned about the quality and cost of education. The education grant is very generous, but it does not cover all of the costs and it requires effort on the part of the parents to obtain their reimbursement. Some parents found that schools did not respond to their e-mail inquiries and they became anxious about finalizing this important aspect of their transition.

The participants agreed that beginning discussions with the schools early is important. Parents can investigate each school's curriculum by visiting their websites. The schools also host open houses and private tours that allow parents the opportunity to visit before making a decision. ISPO and the UNWG have a list and description of international schools in Vienna which can be found in their Career Guide at http://www.iaea.org/unwg/members.html. Most parents choose the private international schools for their children, but it is also possible to send children to Austrian schools. If considering an Austrian school, it is best if the child is young or already has German language skills. It is not necessary, in either case, to live in the same

\footnotetext{
${ }^{4}$ The video can be viewed at http://www.bnl.gov/aiov/highlights.asp.

${ }^{5}$ The raw results are presented in Appendix D without prejudice or modification except to edit them to better communicate the message of the participants. The workshop organizer and the authors of this report do not agree with all of the comments.
} 
district as the school is located. A host family with children should be assigned to any newcomer family with children so that the newcomers can learn from the experiences of the host family. ${ }^{6}$

\subsection{Family Adjustment}

There are many adjustments to be made when accepting a foreign work assignment. Each family member is affected in a different way. The I/O employee is challenged to work in a multicultural environment. The trailing partner may find it difficult to find employment. Children will want to fit in among their peers at school. For married couples without children, the transition can be more challenging for the spouse/partner because it is hard to make connections.

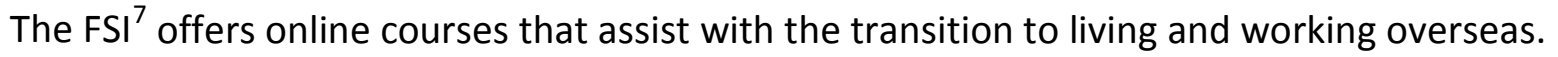
There are particular courses that target different age groups for the children, such as the teenager or the younger person. Also offered are language courses, cultural training, and safety awareness.

Sports activities and German language cartoons are ways for children to increase their language skills. Prior to moving to Vienna, adults can contact individuals already living in Vienna, through social networks such as LinkedIn (Americans@IAEA group) or the USVienna.com interactive website, to begin establishing networks that can help them and their families prepare for the transition.

Having a connection with the child's school, and to other parents, aids an individual in building relationships and developing a sense of belonging. Additional resources for support systems are available by joining groups such as the AWA, www.awavienna.com, and the Vienna Babies Club at www.viennababiesclub.com. Patience Gebauer, VIC staff counselor, offers counseling for the entire family at no cost.

Settling in to life in Vienna depends upon the clear choices that are made prior to arrival. Applicants should consider the length of stay versus the likelihood of employment for the partner, and other non-employment activities that the spouse/partner can do. They should consider whether they can manage on one salary. With either decision it is important for the partner to establish his/her own identity. Utility accounts, bank accounts, credit cards, internet and cable access should be arranged in both parties' names.

\footnotetext{
6 The Host Family Program is organized by ISPO using volunteers who completed their transition to Vienna to host newcomers who can benefit from their experience.

${ }^{7}$ For further information, email the FSI Transition Center at FSITCTraining@state.gov or visit the FSI Transition Center website at http://www.state.gov/m/fsi/tc/fslstraining/searchbymonth/index.htm.
} 
Resources are available to assist the spouse/partner seeking employment in Vienna. Contact the ISPO recruiter, the UNWG, and the Vienna Expat Center for further information. Make an effort to learn the German language.

\subsection{Housing}

The IAEA and other I/Os at the VIC set up the VIC Housing Service to help employees' secure reasonable rented accommodation and advice on leasing agreements. The service is free of charge. Participants recommended that the IAEA allow new recruits to come to Vienna for a house hunting trip prior to the start of their assignment. Although that currently is not an option, new hires can register online with the Housing Service while still in the United States at vichousing.iaea.org. In that way, one can become acquainted with the housing market and perhaps even identify potential accommodations for viewing when arriving in Vienna. Some participants felt it took more time than they expected to find suitable housing. On average it takes about one to three weeks to find suitable housing and complete the contract, even with the help of the UN Housing Service. They have helped most people secure reasonable rented accommodation and advised them on issues. It is advisable to go to the Housing Service on the first day of work, either to follow up on your earlier requests or to register for their service. The VIC Housing Service will contact landlords to coordinate appointments. They can assist in negotiating and preparing a contract in German and in English. If the owner prefers to use a standard local contract, this should be reviewed and, if required, modified by the Housing Service or another expert. There are less expensive apartments for rent than what is offered by VIC Housing; however there are disadvantages to pursuing these options including the cost of working with a real estate agent, unsupported interactions with an Austrian landlord, and interpreting a local contract.

For the first week or so, it may be easier to reserve a room at a hotel or pension while looking for a place to live. If requested, the IAEA will reserve temporary accommodations. A housing request form is sent to appointees along with the contract.

For those wishing to do their own search, the Web is a useful resource. Real Estate sites include http://www.business-apartments-vienna.at/Home.html, http://derstandard.at/Immobilien, and http://www.willhaben.at/iad/immobilien/. Other assistance includes local real estate agents, the classified section of a newspaper, and craigslist.at. Apartments may be advertised through USVienna.com website and LinkedIn networks.

Assigning a host family with similar make up enables the newcomer's family to learn from the experiences of the host family. A relocation agency can provide similar, professional support for a fee. The Vienna Expat Center can be helpful in identifying a relocation agency (http://www.expatcenter.at/index.php?id=1\&L=1). 
Rental agencies charge a fee of two to three months' rent and many landlords expect a three month security deposit due at contract signing. This expense can be offset by the installation grant $^{8}$ and sometimes can be paid over the first few months of the contract. Reliance on the housing subsidy ${ }^{9}$ can be a concern for the long-term; over time the housing subsidy will decline, and the renter will have to make up the difference.

\subsection{Employment}

In past years, employment was not easy to obtain for the spouse/partner. Circumstances regarding unfamiliarity with the German language, not being a citizen of an EU country, and the complexity of obtaining a work permit presented barriers.

Recently, the Austrian government opened the local job market to non-EU citizens by establishing the Austrian red-white-red card program. This application system will specifically assist U.S. citizens by enabling them to compete for employment within Austria. ${ }^{10}$ The ISPO website ${ }^{11}$ has been updated to include a webpage for Overseas Assistance. ${ }^{12}$ Within the Tips for Newcomers page ${ }^{13}$ there is a link to the recently completed UNWG Career Booklet. ${ }^{14}$ This book contains many references and ideas for employment that the spouse/partner can pursue while living in Vienna. The webpage also points to a list of U.S. subsidiaries located in Austria. Spouses/partners of new hires can investigate employment with one of these companies before moving to Vienna with the intention of transferring to an office in Vienna or elsewhere in Europe. This will also relieve the burden of applying for a work permit. Hilary Warmoth, career coach, can assist with reinventing job skills and qualifications.

Some individuals are not concerned about working. There are numerous opportunities for other activities. One can volunteer, take classes, pursue certification, travel, assist one's children or sightsee.

\footnotetext{
${ }^{8}$ An internationally recruited professional staff member with a fixed-term contract of at least one year is entitled to an assignment grant to cover initial, settling-in expenses.

${ }^{9}$ The IAEA provides a rental subsidy for newcomers to ensure a greater degree of equity and alleviate hardship for those whose rental costs significantly exceed the average for the duty station. The subsidy is based on an algorithm that takes into account the staff member's professional level, salary, and number of family members in residence. The subsidy cannot be more than $40 \%$ of the actual rent and will decrease with time.

${ }^{10}$ More information on the red-white-red card can be found at https://www.help.gv.at/Portal.Node/hlpd/public/content/12/Seite.120308.html. This page may require translation.

${ }^{11}$ www.bnl.gov/ispo.

12 http://www.bnl.gov/ispo/recruitment/overseas_assistance.asp

${ }^{13}$ http://www.bnl.gov/ispo/recruitment/Tips_for_Newcomers.asp

${ }^{14}$ http://unwg.unvienna.org/pdf_list/Career_2011.pdf
} 


\subsection{Long Distance Relationships}

In some cases one partner desires the foreign assignment more than the other or the trailing spouse has commitments that make it impossible to relocate for even a short time. These partners may decide to live separately for the term of the I/O assignment. Some companies allow telecommuting which might enable a couple to go to Vienna together. Unmarried partners, including same-sex partners, have found that the IAEA does not recognize their relationship officially. Although recognition of unmarried partners has improved in recent years, the partner still needs to apply for legitimization on his/her own. Obtaining dual citizenship, if eligible, through one of the EU countries, can provide access to benefits and rights that are not extended to these U.S. citizens. Austria now acknowledges cohabitating same sex partners which makes life in Vienna a bit less complicated.

When the couple decides that one will remain in the United States, other difficulties can arise. Communication can be strained due to the time difference, especially for individuals residing on the west coast of the United States. Talking, eating, watching the same movie, or reading the same book via Skype or Magic Jack technology can alleviate some of these difficulties.

\subsection{Pre-Field Orientation to Vienna}

Orientation for the newcomer in Vienna can be difficult to obtain for a few reasons. ISPO and ANL are not always aware of the new person's appointment, the IAEA has infrequent courses, the individual does not know who to contact for information prior to the move, and U.S. citizens are hired sporadically throughout the year.

Given the current conditions, it is clear that other mechanisms must be put into place in order to prepare the appointee and family for life in Vienna. ISPO conducted an orientation at BNL in September 2010 for 13 Cost Free Experts (CFEs) and Junior Professional Officers (JPOs) who were recruited around the same time. The participants received copies of the AWA's Living in Vienna ${ }^{15}$ and The Art of Crossing Cultures. ${ }^{16}$ The attendees appreciated the orientation and have remained in touch since. ISPO suggested annual orientations at BNL.

Several guidebooks are available. The AWA's Living in Vienna is a comprehensive guide for getting around in Vienna, www.awavienna.org. The UNWG, http://unwg.unvienna.org, as well as the Vienna Service Office, both located in the VIC, have a list of volunteers per district, called "Friends of Vienna," that will assist the newcomer with familiarization within their district. The Vienna Expat Center recently developed a guide book for the expatriate in Vienna that was released in May 2012.

\footnotetext{
15 "Living in Vienna," published by the American Women's Association of Vienna, $25^{\text {th }}$ Anniversary Edition.

${ }^{16}$ Storti, Craig, The Art of Crossing Cultures, Second Edition, Intercultural Press, 2007.
} 
The participants found the AIOV workshop to be an excellent source of information. Periodic gatherings, such as brown bag lunches, could provide continued assistance and support to the I/O community. A VIC Club for Americans working at the VIC would encourage the community to sustain itself over time.

Other useful links and organizations are:

- the Women's Career Network (WCN) www.wcnvienna.org,

- Austro-American Society www.auamsoc.at,

- Linkedln - Americans @ IAEA, www.linkedin.com/groups?gid=2144464,

- ISPO, www.bnl.gov/ispo,

- Expats on Foreign Assignment, www.foreignassignment.com,

- Democrats Abroad, www.democratsabroad.org/group/austria,

- the American Expatriates Blog, www.expat-blog.com/en/nationalities Lamerican/in/europe/austria/vienna/, and

- the Foreign Service Institute for orientation courses http://fsitraining.state.gov.

ISPO should pay the most attention to new hires in the month before they move. This period of time is hectic and confusing.

\subsection{Singles}

The IAEA human resources introduction package is family oriented. It is difficult for singles to meet other singles. In 2002, the USSP started the USSP internship program for the Department of Safeguards. The internship program has since developed and grown into the JPO program which provides entry level positions to recent graduates with relevant degrees. The JPOs are usually single without dependents. There is a need to consider singles when preparing orientation materials and classes.

Singles do not have the built-in support structure that a partner provides. They must consider where to live safely, they need to take time off from work to arrange services (cable, phone, maintenance), and they need to have an emergency point of contact who is local. Singles should reach out to co-workers, take part in events, join a VIC club, or visit the Vienna Expat Center. Facebook, LinkedIn, and InterNations are good outlets for networking with other expatriates. Often children of families look for some work to do. They can assist the single person by waiting for the chimney sweeper and/or walking dogs.

\subsection{Retirement}

Retirees of the Vienna I/Os must decide whether to remain in Vienna or to return to the United States. The mandatory retirement age at the IAEA is 62. Some Americans want to work longer. 
In previous years, it was much easier to retire in Austria than it is today. Even though one has worked as a UN employee and lived in Vienna for the duration, it is required that retirees become legal residents of Austria if they intend to stay in the country. Purchasing real estate without being an Austrian citizen can be difficult. Elmar Drabek, of the law firm Dorda, Brugger and Jordis, Elmar.drabek@dbj.at, can provide assistance in this regard.

Retirees living in Vienna could serve as volunteers for the Host Family program.

\subsection{Shipping of Household Effects to and from Austria}

Rules and procedures regarding shipping of household items, customs, and immigration require clarification. The costs, approximate date of arrival in Austria and delivery dates are not reliable. Participants would have liked a do-it-yourself option; they would like to have more control.

New IAEA employees are given a storage allowance. Once the allowance is expended, which will be quicker for larger storage quantities, the employee will have to assume the expense or make other arrangements, e.g., reduce their belongings.

\subsection{Transition}

Prior to arrival, most participants needed more information to be comfortable with their relocation. They wanted to know what steps they should follow. Others needed more information regarding importing animals and caring for pets in Vienna. Some individuals may have a lapse in insurance coverage from the former employer to the new employer. Several recommended the COBRA plan for the interim. With regard to transition upon arrival in Vienna, the participants suggested that ISPO or ANL conduct a survey or follow up with the newcomer after they have been in Vienna for six months. The newcomers may identify experiences that aren't immediately known on arrival, and which can be documented and shared with others.

For help with the transition to Vienna, the ISPO webpage on Overseas Assistance has many valuable tips and references regarding the transition before, during and after arrival in Vienna and other sources/links for adapting to life in Vienna. Networking groups such as Americans@IAEA on LinkedIn, the USVienna.com community forum, the ISPO website, and the Vienna Expat Center are additional resources for acquiring knowledge prior to arrival. It is also advisable to register with the U.S. Embassy while in Vienna.

When a recruit is short-listed for a position, he/she can contact a USSP representative for guidance. The ISPO and ANL offices can assist with books, material, and literature, answer questions, and offer advice and direction. Once the newcomer has been selected by the IAEA, ISPO and ANL can assign a host family to greet and assist the expatriate in Vienna. 


\subsection{Medical}

The VIC medical facility can provide lists of doctors. Participants suggest getting recommendations from other Americans. While medical care in Vienna is of the highest quality, some doctors have procedures that are inconsistent with U.S. standards. English speaking doctors are not always the best. More information on medical services can be found by visiting the U.S. Embassy website ${ }^{17}$ and the City of Vienna website. ${ }^{18}$ Both offer an extensive list of doctors. One may search by type of practice, vicinity and/or language preference.

\subsection{Repatriation}

After living and working in Vienna for some time, one may experience a reverse culture shock when returning to the United States. Friends and family may have moved, prices of commodities can significantly change, and specific aspects of daily life may be different. A specific example of reverse culture shock is grocery shopping: U.S. stores are much larger, offer more product choices, and are more convenient, but they can be overwhelming.

If the employee came from a national laboratory, he/she may be on a leave of absence and be able return to a familiar job and colleagues. In this case, the transition will be easier. If there is no arrangement to return to one's previous place of employment, it may be difficult to find employment. Some employers do not want to consider candidates from overseas due to the expense associated with relocating them. Employers may not know that the IAEA pays repatriation expenses. It is best to be aware of the situation and plan ahead. Prior to contract end, distribute resumes, gather employment contacts, identify employment opportunities, network with societies, join professional organizations, use LinkedIn, and contact ISPO for assistance and recommendations.

\subsection{Personal}

There are emotional aspects about leaving a familiar life behind and starting a new one. Dr. Panakkal noted that people should give themselves about six months to adjust to being in a new country and being away from their home country. People lose connections with family and friends. There is a tendency to isolate one's self. Parents may be aging and need assistance. One misses important family and cultural events. Talking to people, making connections, exploring the environment, arranging dinners, and joining clubs are just some of the positive activities that can assist with adaptation and ease the sense that one is missing out on events at home.

${ }^{17} \mathrm{http}: / /$ austria.usembassy.gov/med.html

${ }^{18}$ http://www2.aekwien.at/997E.py 
The JPOs and the cost-free experts expressed worries over their contract expiration and extensions. It is time consuming to rent an apartment, learn the new job, get settled in Vienna and learn the environment. JPOs and some CFEs receive one year contracts. The effort required to move to Vienna and establish one's self there may not seem worth it for that short period of time.

Landlords require three months' notification prior to departure. The USSP is aware that contract extensions have to provide sufficient notice for the JPOs and CFEs to make arrangements to extend their stay or leave Vienna.

\subsection{Miscellaneous}

Newcomers experience a language barrier if they have no previous knowledge of German. Vienna is an expensive city. The shopping hours are shorter than in the United States and can be inconvenient. U.S. entertainment is not readily available. It is easy for employees to cocoon themselves in the "UN bubble" and never experience Vienna or Austria.

Studying German before or after arrival and watching German language TV can help with the language barrier. Most Austrians speak some English. Being able to speak a few German phrases will encourage Austrians to use their English language skills to help. ISPO has a multiuser Rosetta Stone license and offers user accounts to U.S. citizens in Vienna. Continued periodic meetings to bring new and seasoned employees together will help the adaptation process and assist the community. The participants would appreciate a subsidy for cultural activities. There are services for gaining access to U.S. TV programming.

\subsection{Summary}

Attendees recommended continuation of this workshop's outreach in the form of periodic brown bag lunches and a second similar workshop in Vienna. Brown bag lunches or "miniworkshops" would be held to use the results from the Breakout Group Sessions as the topics for discussion. The raw results document would be referenced for clarification, verification, and for additional suggestions. Expert speakers could be invited to attend these luncheons to help on topics that would require more in-depth knowledge. The main goal or purpose of these luncheon discussions would be to invite newcomers and experienced expatriates, for networking, to develop a support system, and to improve communication and information for the U.S. citizen living and working in Vienna, Austria.

ISPO's observations based on the results are:

1. Many of the comments apply to life in the United States as well. They are only noteworthy because they are experienced in an unfamiliar location. 
2. Networking is very important - for adapting, developing support networks, and finding employment.

3. There are many services available; the challenge is finding them when one needs them.

4. The re-establishment of the Host Family Program and the ISPO Orientation could help address a number of the recommendations.

5. The problems that singles encounter are also experienced by families, but they are exacerbated by lack of support from a close relation.

Near term recommendations:

a. Reinstate the Host Family program and maintain an active list of volunteers;

b. Organize a VIC Club to include events for Americans and brown bag lunches; and

c. Follow up with newcomers to supply them with material and support for the transition. Medium term recommendations:

a. Maintain the USVienna.com website and the ISPO website with current and useful information; and

b. Prepare and improve relevant brochures.

Long term recommendations:

a. Sponsor an AIOV workshop every two years in Vienna; and

b. Assist the UNWG with updating of their Career Guide.

Overall, not only did this workshop provide significant, beneficial information to attendees, but the observations and recommendations will help the U.S. Mission and U.S. government address ways to better promote Foreign Service employment and support for Americans transitioning overseas.

\section{WORKSHOP ARCHIVE}

Project documents will be available on the ISPO website at www.bnl.gov/ispo/events.asp, and on BNL's website at www.bnl.gov/aiov.

Final documents will be archived in the ISPO Information System Library. Please contact ISPO at staffing@bnl.gov for access to the documentation. This report will be archived as ISPO-544. 


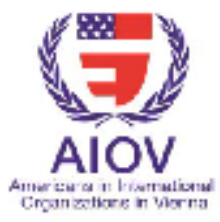

The NH Hotel - Danube Wagramer Strasse 21

\section{October - 04 October 2011}

\section{Workshop AGENDA}

\section{Monday, 03 October}

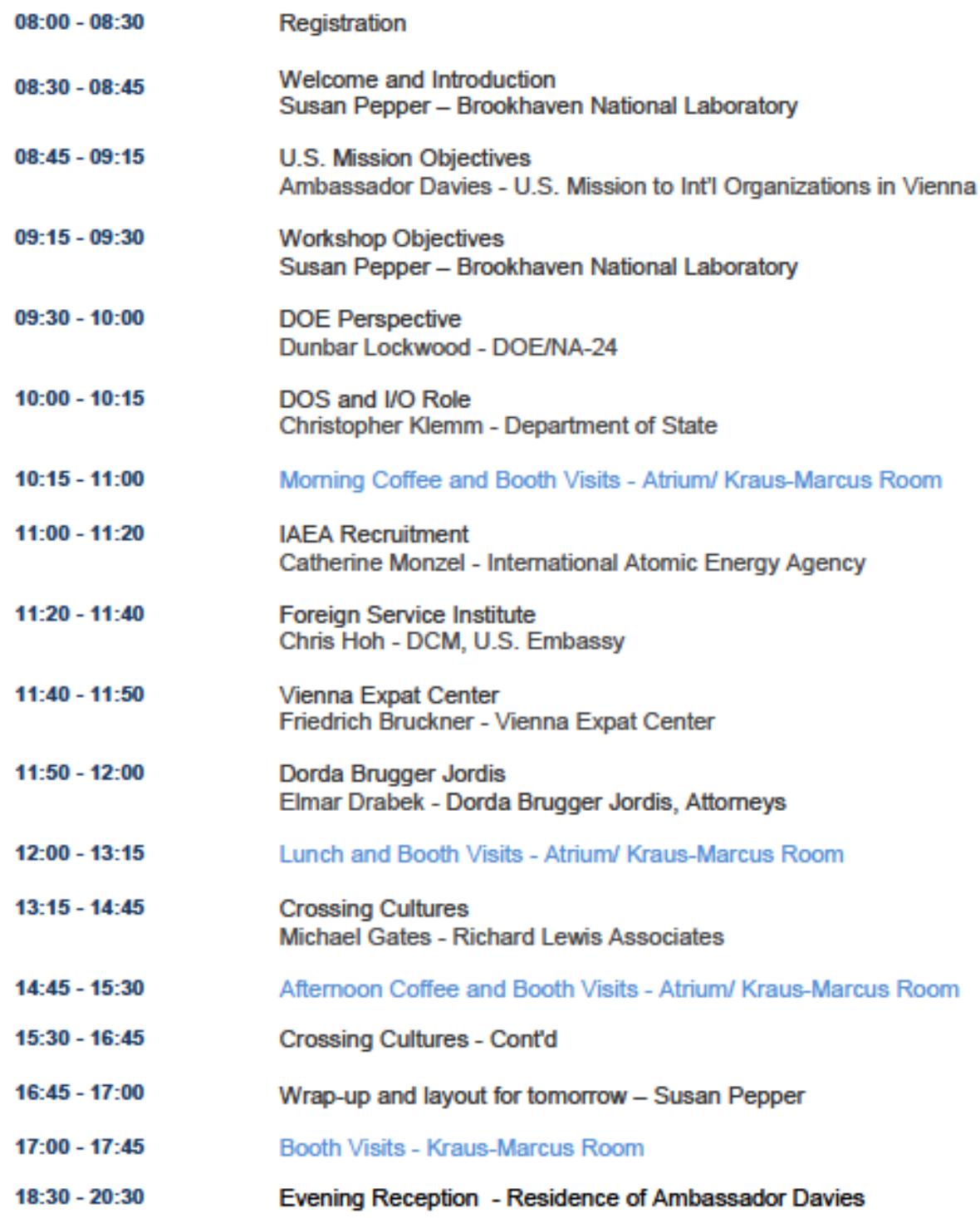




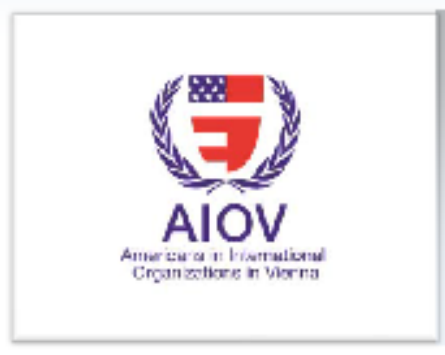

\section{The NH Hotel - Danube}

Wagramer Strasse 21

03 October - 04 October 2011

Workshop AGENDA

\section{Tuesday, 04 October}

\begin{tabular}{|c|c|}
\hline 08:30 - 09:00 & Registration \\
\hline 09:00 - 09:15 & $\begin{array}{l}\text { Welcome and Introduction } \\
\text { Susan Pepper - Brookhaven National Laboratory }\end{array}$ \\
\hline 09:15 - 09:45 & $\begin{array}{l}\text { Career Shock } \\
\text { David Panakkal - U.S. Embassy }\end{array}$ \\
\hline 09:45 - 10:15 & $\begin{array}{l}\text { Career Adjustment } \\
\text { Lydia Goutas - Lehner Executive Partners }\end{array}$ \\
\hline 10:15-11:00 & Morning Coffee and Booth Visits - Atrium/ Kraus-Marcus Room \\
\hline \multirow[t]{3}{*}{$11: 00-12: 00$} & $\begin{array}{l}\text { Form Break-out Groups: } \\
\text { Married with children; Married without children; Singles }\end{array}$ \\
\hline & $\begin{array}{c}\text { Facilitators - JoDee Martinez, Pearl and Brian Williams, } \\
\text { and Kaisa Clark } \\
\text { Notetakers - Laura MacArthur, Susan Pepper, } \\
\text { and Ashley Wroten }\end{array}$ \\
\hline & Location: Gustav Mahler and Sigmund Freud Rooms 2 and 3 \\
\hline 12:00 - 13:00 & Lunch and Booth Visits - Atrium/ Kraus-Marcus Room \\
\hline 13:00 - 15:00 & Resume Break-out Groups \\
\hline 15:00 - 15:45 & Aftemoon Coffee and Booth Visits - Atrium/ Kraus-Marcus Room \\
\hline $15: 45-16: 00$ & $\begin{array}{l}\text { American Consulate } \\
\text { Catherine Muller - U.S. Consulate }\end{array}$ \\
\hline $16: 00-16: 30$ & $\begin{array}{l}\text { Safety Abroad } \\
\text { Mary Jo Swinimer - U.S. Embassy, Regional Security Office }\end{array}$ \\
\hline $16: 30-17: 00$ & $\begin{array}{l}\text { Breakout group results } \\
\text { Review Activities and Closing }\end{array}$ \\
\hline
\end{tabular}




\section{Vendor Contact List}

for the AIOV Workshop

\begin{tabular}{|c|c|c|c|}
\hline Association & Point of Contact & Email address & Note \\
\hline $\begin{array}{l}\text { Argonne National Laboratory } \\
\text { Brookhaven National Laboratory }\end{array}$ & \begin{tabular}{|l} 
Paola Luchi \\
Tanya Collins \\
\end{tabular} & $\begin{array}{l}\text { mammaluc@verizon.net } \\
\text { tcollins@bnl.gov }\end{array}$ & \\
\hline American Women's Association & Laurie Richardson & $\begin{array}{l}\text { viennaawa@gmail.com; or } \\
\text { awa@awavienna.com }\end{array}$ & \\
\hline $\begin{array}{l}\text { Dorda, Brugger, Jordis Attnys at } \\
\text { Law }\end{array}$ & Elmar Drabek, B.A. & Elmar.drabek@dbj.at & Immigration Law \\
\hline Foreign Service institute & $\begin{array}{l}\text { Chris Hoh } \\
\text { Kathleen Alexander }\end{array}$ & AlexanderKJ@state.gov & $\begin{array}{l}\text { Provided a binder } \\
\text { with course listings }\end{array}$ \\
\hline $\begin{array}{l}\text { International Atomic Energy } \\
\text { Agency }\end{array}$ & $\begin{array}{l}\text { Catherine Monzel } \\
\text { Kaisa Clark } \\
\text { Naomi Bichler-Bell }\end{array}$ & $\begin{array}{l}\text { C.Monzel@iaea.org } \\
\text { K.Clark@iaea.org } \\
\text { N.Bichler-Bell@iaea.org }\end{array}$ & $\begin{array}{l}\text { Available for any } \\
\text { questions }\end{array}$ \\
\hline International Christian School & $\begin{array}{l}\text { Brian Williams } \\
\text { Laura Mason } \\
\text { Pearl Williams }\end{array}$ & pwilliams@vcs-austria.org & \\
\hline $\begin{array}{l}\text { MA-35, Immigration and } \\
\text { Residency }\end{array}$ & Ms. Gabriele EL-HOURINY & & Vienna City Hall \\
\hline Untied Nations Women's Guild & Ritu Halder & ritu.halder@gmail.com & \\
\hline Vienna Expat Center & \begin{tabular}{|l} 
Friedrich Bruckner \\
Ms. Sidonia Mussner
\end{tabular} & Bruckner@wirtschaftsagentur.at & \\
\hline Vienna Service Office & Angelika Wolfer & viennaserviceoffice@unvienna.org & \\
\hline Women's career Network & Caterina Galea & $\begin{array}{l}\text { presidents@wcnvienna.org } \\
\text { galea.caterina@yahoo.de }\end{array}$ & \\
\hline Webster Unviersity & Teresa Sedlar & sedlar@webster.ac.at & \\
\hline
\end{tabular}




\section{APPENDIX C. Presenters' Biographies}

\section{U.S. Mission Objective}

Ambassador Glyn Davies has served as Permanent Representative of the United States to the International Atomic Energy Agency and the United Nations Office in Vienna since 2009. He leads a Mission of more than 2 dozen employees from the Department of State, the Department of Energy, and the Nuclear Regulatory Commission. The U.S. Mission works to achieve U.S. foreign policy goals within 8 international organizations in Vienna on a range of issues such as preventing nuclear weapons proliferation, promoting safe and secure peaceful nuclear technologies, monitoring nuclear explosions, fighting illegal narcotics trade, curbing international organized crime, controlling the transfers of conventional weapons, and supporting the peaceful uses of outer space.

Ambassador Davies is a career foreign service officer. Before coming to Vienna, he served as Principal Deputy Assistant Secretary of State in the Bureau of East Asian and Pacific Affairs. He has held senior positions in the Bureau of Democracy, Human Rights and Labor; the Bureau of European Affairs; and the U.S. Embassy in London. He served as Executive Secretary of the National Security Council Staff, and as Deputy Spokesman for the State Department. He's also had assignments in Paris, Melbourne, and Kinshasa."

\section{Workshop Objectives}

Susan Pepper holds a Bachelors and Masters of Science in Civil Engineering from the Massachusetts Institute of Technology. Ms. Pepper began her career at Brookhaven National Laboratory (BNL) in the Department of Nuclear Energy's Structural Analysis Division. In 1993 she joined the International Safeguards Project Office (ISPO) and in 1994 became the ISPO Liaison Officer posted at the U.S. Mission in Vienna, Austria. As Liaison Officer, Ms. Pepper was responsible for interacting with IAEA staff to ensure that the activities of the U.S. Support Program were meeting their needs. In 1998, she returned to BNL where she became the head of ISPO. She has been the Coordinator of the U.S. Support Program to IAEA Safeguards since 1996. She has been the Deputy Chair of the Nonproliferation and National Security Department since September 2010.

\section{DOE Perspective}

Dunbar Lockwood works for the National Nuclear Security Administration (NNSA) as a Team Leader for International Safeguards Policy in the Office of Nonproliferation and International Security (NA-24). Among other things, he has responsibility for managing three program elements of the Next Generation Safeguards Initiative (NGSI) - Policy, Concepts and Approaches and Human Capital Development. Before joining NNSA in 2003, Mr. Lockwood worked for nine years at the U.S. Department of State and the Arms Control and Disarmament Agency (ACDA) on nuclear arms control and nonproliferation issues, including the CTBT, FMCT, and START III talks. Prior to starting in the federal government in 1995, he was the Assistant Director for Research at the Arms Control Association (ACA). Mr. Lockwood has published numerous articles and book chapters on arms control and non-proliferation issues. He received his Master's Degree in Security Policy Studies from George Washington University's Elliot School in 1985.

\section{DOS and I/O Role}

Christopher Klemm is the Lead Staffing Management Officer at the U.S. Department of State in the Office of UN Employment and Assistance. Mr. Klemm is responsible for advocating on behalf of 
Americans seeking professional positions at the United Nations and other international organizations. Prior to working at the Department, Mr. Klemm was a Management Officer at the U.S. Agency for International Development. He holds a Master's Degree in Industrial and Labor Relations from Indiana University of Pennsylvania.

\section{IAEA Recruitment}

Catherine Monzel is head of the Recruitment and Staff Development Section in the IAEA's Division of Human Resources. Ms. Monzel leads a group in charge of a human resources management system ranging from recruitment to outreach activities aimed at attracting candidates of the highest standards, with an emphasis on professional women.

\section{Foreign Service Institute}

Christopher Hoh is the Deputy Chief of Mission at the U.S. Embassy in Vienna arriving at post in June 2009. Prior to arriving in Vienna he served as Associate Dean at the Foreign Service Institute of the United States Department of State outside Washington, D.C. Mr. Hoh a career member of the U.S. Foreign Service, has been assigned to Bonn, Germany; the United Nations in New York; Lima, Peru; the State Department in Washington, D.C. and as a peacekeeping observer in Egypt's Sinai desert.

\section{Vienna Expat Center Services}

Friedrich Bruckner was hired by the city of Vienna in 2010 to join the team of the Vienna Expat Center from its foundation in September of 2010. His main responsibilities are individual consulting of expatriates as well as networking with various expatriate communities and organizations. He resides in Austria with his wife who is an Expat herself from Germany.

\section{Immigration Topics}

Elmar Drabek is the head of the corporate migration and citizenship practice group at DORDA BRUGGER JORDIS Attorneys at Law, Vienna - AUSTRIA. Mr. Drabek received his legal education at the University of Vienna and Penn State University (Dickinson School of Law). Prior to joining DBJ in 2004, he represented asylum-seekers and migrants in appellate cases on behalf of UNHCR, the Austrian Red Cross, amnesty international and Caritas Austria. He is the author of several expert publications on immigration law and regularly lectures on topics of immigration law and administrative procedure at specialized conferences.

\section{Crossing Cultures}

Michael Gates is Group Managing Director for Richard Lewis Communications - a UK-based international organization in the field of cross-cultural training. Michael took his M.A. in English Language and Literature at Oxford University, where he was a Scholar of St. Catherine's College. Before establishing the Finnish branch of Richard Lewis Communications in 1990, he had worked in radio production with some of the top names in British entertainment.

He has been involved in cross-culture for the last 17 years, supporting dozens of blue-chip companies world-wide, including; Nokia, Microsoft, the World Bank, Duke University and the Austrian Office of the Chancellor. Richard Lewis and he developed the concept of cultural profiling in Finland, as part of the preparations for their successful EU Presidency in 1999 and in 2006. He also conducted a cross cultural training seminar for the Austrian Office of the Chancellor (Bundeskanzleramt Österreich) in 2009 in preparation for their EU Presidency and again in October 2010.

His presentation of the culture active tool for cultural profiling won the award for the 'most innovative technology' panel at the CIBER Global Interdependence conference at the University of North Carolina in 
March 2002. He has taught the cross-cultural module to new MBA students at Duke Fuqua business school, North Carolina, and other US clients have included Microsoft, the World Bank and Accenture. European clients include Nokia, Teliasonera, the Hertie School of Governance, Berlin and Oxford University, UK. He has published jointly with Richard Lewis, including some observations on Finnish leadership. He is a board member of the Finnish-British Trade Association.

He is of mixed British/Austrian parentage, lives near Helsinki, is married to a Finn, and has five children.

\section{Career Shock}

David Panakkal is the Regional Medical Officer for the Tri-Mission in Vienna. He was the Director of Mental Health Services for the State Department and previously served in Iraq/Pakistan/Afghanistan.

\section{Career Adjusting}

Lydia J. Goutas is a managing partner at Lehner Executive Partners serving Austrian and Multi-National industries and is often called upon to share her understanding of local and international HR issues. Prior to this she worked for many years at Webster University including several years as managing director of their Professional Development Center which included the IAEA among its clients. In addition to her professional activities, Lydia has been a board member and past president of the American Women's Association and is Co-Chair of the futurist Board level banking group Financial Services Club Austria and Central Europe.

\section{American Consulate Services}

Catherine Muller is a Public Diplomacy Officer with the Department of State. She is currently serving as a Vice Consul at the U.S. Consulate and has been living in Vienna for two years. She has worked in the Bureau of Political Military Affairs at the Department of State and previously worked on foreign and military policy issues on Capitol Hill. She holds a Master's degree in International Affairs and National Security from Texas A\&M and speaks four languages.

\section{Safety Abroad}

Mary Jo Swinimer is the Regional Security Officer at the U.S. Embassy in Vienna, Austria and is responsible for security at all three U.S. Missions. Prior to Vienna, she served as the Executive Assistant for the Assistant Secretary of Diplomatic Security in Washington, DC. She has served in U.S. Missions in Sarajevo, Bosnia, Moscow and St. Petersburg, Russia, Kingston, Jamaica and Frankfurt Germany. During her 25 years of service, she has received numerous performance awards and commendations. She graduated from Georgetown University with a Bachelor of Science in Foreign Service in International Relations and from the U.S. Naval War College with a Master's degree with highest distinction in National Security and Strategic Policy. 
APPENDIX D. Raw Results of the AIOV Breakout Groups

\begin{tabular}{|c|c|}
\hline ISSUES FACING U.S. CITIZENS: & ASSISTANCE: \\
\hline 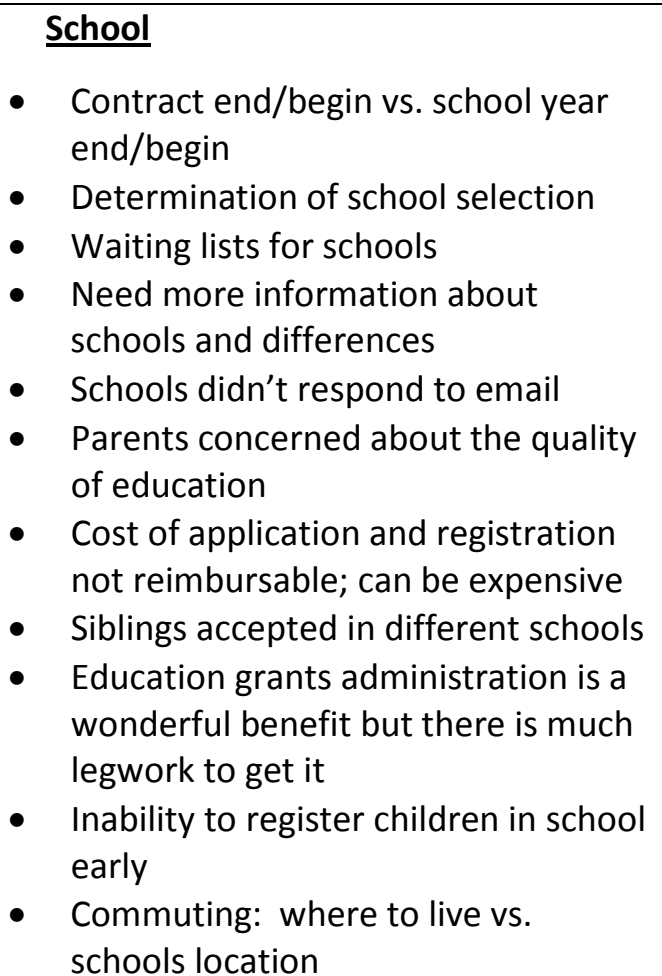 & $\begin{array}{l}\text { School } \\
\text { - Begin discussions with school early on } \\
\text { - Get an inventory of school's offerings/curriculum } \\
\text { - UNWG has a list and description of schools in Vienna } \\
\text { - Identify a Host Family that have children } \\
\text { - Where you attend school does not depend on the } \\
\text { - district that you live in } \\
\text { Attend an open-house at the schools in Vienna or } \\
\text { arrange a private tour }\end{array}$ \\
\hline $\begin{array}{l}\text { Family Adjustment } \\
\text { - Family left behind in the U.S. } \\
\text { - Big change for working mom: No } \\
\text { kids, no job } \\
\text { - Kids in college internationally } \\
\text { - Can't see family in the U.S. } \\
\text { frequently } \\
\text { - Children's adjustment difficult } \\
\text { - Took one year } \\
\text { - Kids don't learn much German in } \\
\text { school in Austria } \\
\text { Working partner's extensive duty } \\
\text { travel creates tension at home } \\
\text { - Manage family life without extended } \\
\text { family support } \\
\text { Loss of identity/becoming dependent } \\
\text { on spouse vs. being independent } \\
\text { Uncertainty of contract length } \\
\text { - Does spouse get a job? } \\
\text { - Part-time job vs. loss of }\end{array}$ & $\begin{array}{l}\text { Family Adjustment } \\
\text { - Have children join an Austrian sports teams } \\
\text { - Watching cartoons helps to learn the language } \\
\text { - UN organizations provide } 6 \text { weeks of vacation } \\
\text { immediately and } 2 \text { weeks home leave after } 2 \text { years of } \\
\text { - } \text { Mervice } \\
\text { - Make sure both partners' names are on accounts for } \\
\text { - See brochure on Opportunities for Americans located at } \\
\text { - } \quad \text { www.bnl.gov/ispo/recruitment/brochures.asp } \\
\text { - Visit “Americans in Vienna” on LinkedIn and the } \\
\text { - USVienna.com websites. } \\
\text { - } \text { wWA and the Vienna Babies Club are great resources. } \\
\text { - } \text { www.awavienna.com and the } \\
\text { - Patiennababiesclub.com counseling is available at the VIC in the F Bldg. } \\
\text { - Contact ISPO for a host family: staffing@bnl.gov People } \\
\text { have found that they can manage on one salary }\end{array}$ \\
\hline
\end{tabular}




\begin{tabular}{|c|c|}
\hline ISSUES FACING U.S. CITIZENS: & ASSISTANCE: \\
\hline $\begin{array}{l}\text { dependency benefits } \\
\text { - Teenage life in Austria is different } \\
\text { - more freedom, drinking age is } 16 \\
\text { - driver's license requires a job } \\
\text { - Trailing partner giving up career } \\
\text { - Make sure you can get by on one } \\
\text { salary }\end{array}$ & \\
\hline $\begin{array}{l}\text { Housing } \\
\text { - Don't get locked into the subsidy } \\
\text { - } \quad \text { There are cheaper places for rent } \\
\text { than what is offered by VIC Housing } \\
\text { - You will not stay in the first place you } \\
\text { rent } \\
\text { - Need assistance with initial housing } \\
\text { options } \\
\text { - Housing assistance was terrible; felt } \\
\text { like they spent more than they } \\
\text { needed to } \\
\text { - Leasing an apartment/access to } \\
\text { housing service } \\
\text { Cost of finding an } \\
\text { apartment/security } \\
\text { Dealing with Austrian } \\
\text { landlord/contract/reading a lease }\end{array}$ & 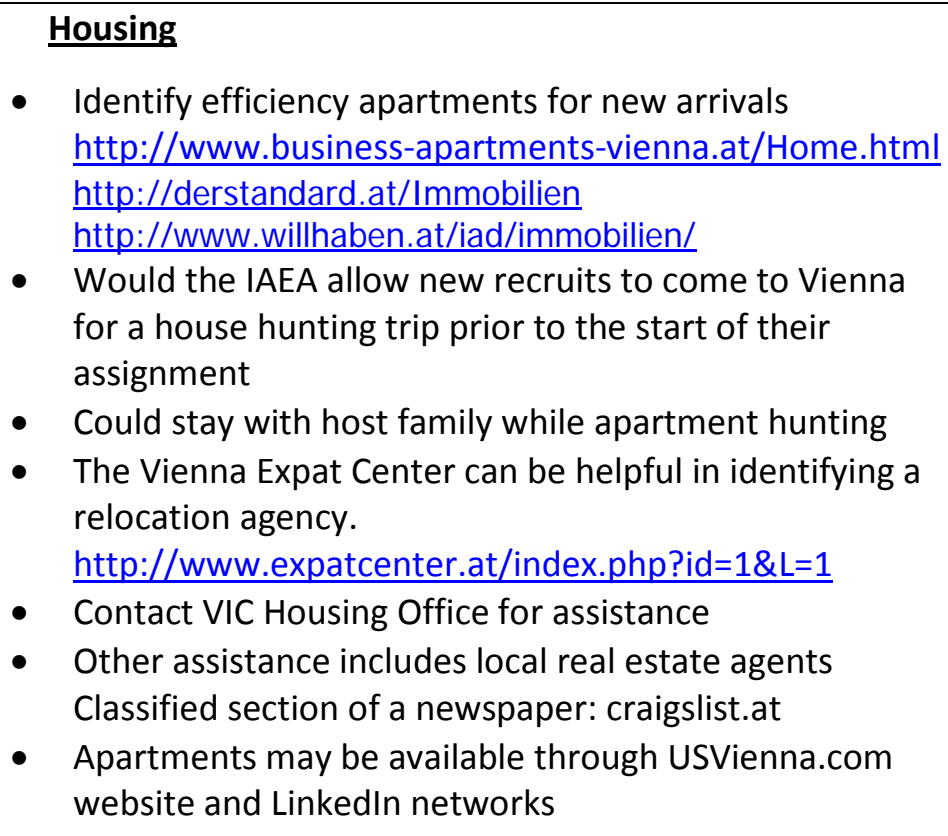 \\
\hline $\begin{array}{l}\text { Employment (partner/spouse) } \\
\text { - Professional certifications have to be } \\
\text { maintained } \\
\text { - Hole in spouse's resume created by } \\
\text { relocation aren't recognized } \\
\text { - Spousal employment } \\
\text { - Some partners not concerned about } \\
\text { - Hot working } \\
\text { - Work permit not easy to get } \\
\text { Spouse stayed in US because unable to } \\
\text { find employment in Austria. }\end{array}$ & $\begin{array}{l}\text { Employment } \\
\text { - Plan ahead to maintain certification } \\
\text { - Could pursue certification while in Vienna } \\
\text { - Education opportunities } \\
\text { - Volunteer work can fill the hole in resumes } \\
\text { - ISPO website: www.bnl.gov/ispo } \\
\text { - UNWG Career Booklet } \\
\text { - List of American subsidiaries in Austria } \\
\text { Career Coach - Hilary Warmoth } \\
\text { - } \text { hnwarmoth@yahoo.co.uk } \\
\text { wustrian red-white-red card available to assist with the }\end{array}$ \\
\hline - $\frac{\text { Long Distance Relationships }}{\text { Recognition of unmarried partners - }}$ & 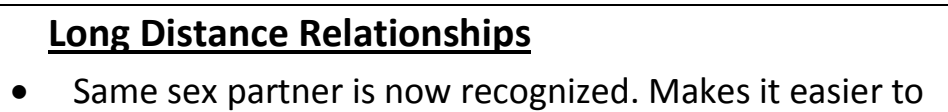 \\
\hline
\end{tabular}




\begin{tabular}{|c|c|}
\hline ISSUES FACING U.S. CITIZENS: & ASSISTANCE: \\
\hline $\begin{array}{l}\text { improved since first assignment } \\
\text { - Communication is difficult (time } \\
\text { difference) }\end{array}$ & $\begin{array}{l}\text { be here } \\
\text { - New technology is helpful (Skype, texting, post cards, } \\
\text { Magic Jack) } \\
\text { - Spouse's job gives him/her flexibility to visit Vienna } \\
\text { often } \\
\text { - Eating, watching TV together via Skype (share daily } \\
\text { experience) } \\
\text { - See the same movie, read the same book }\end{array}$ \\
\hline 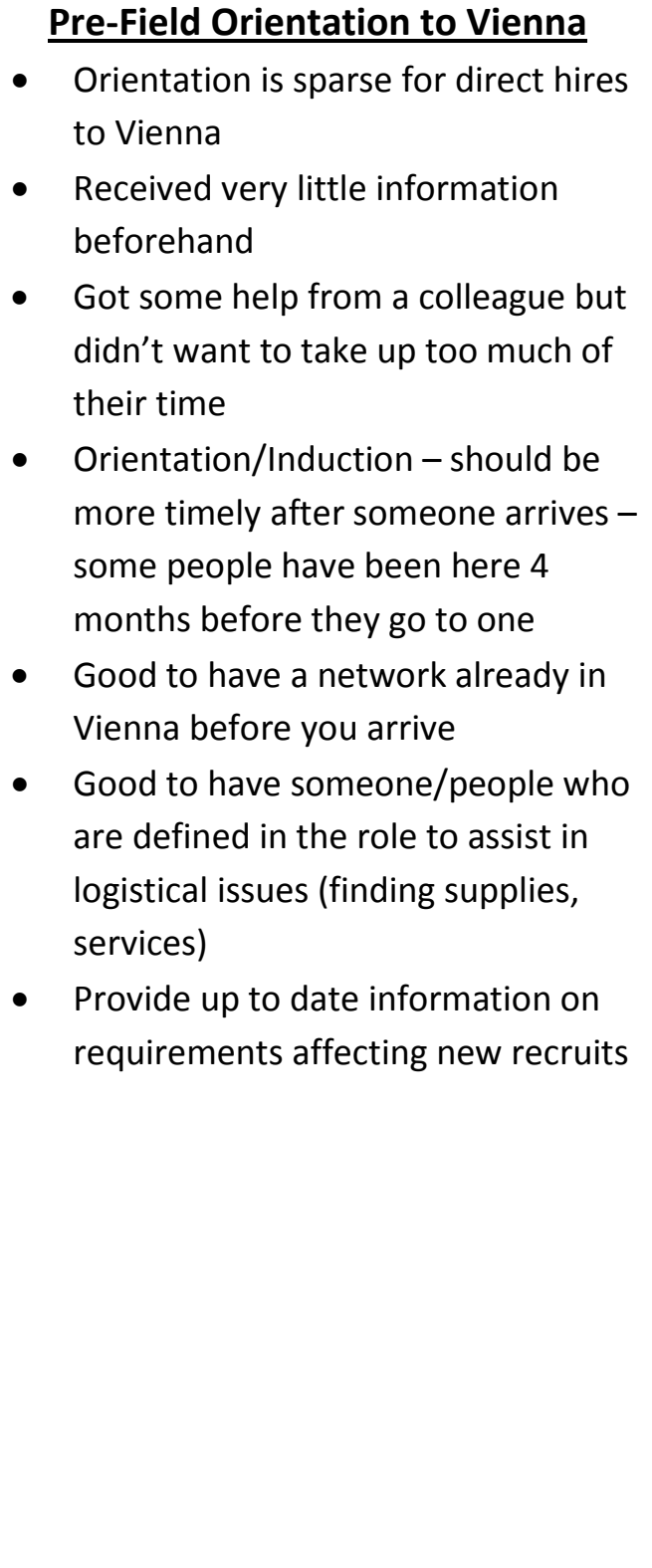 & 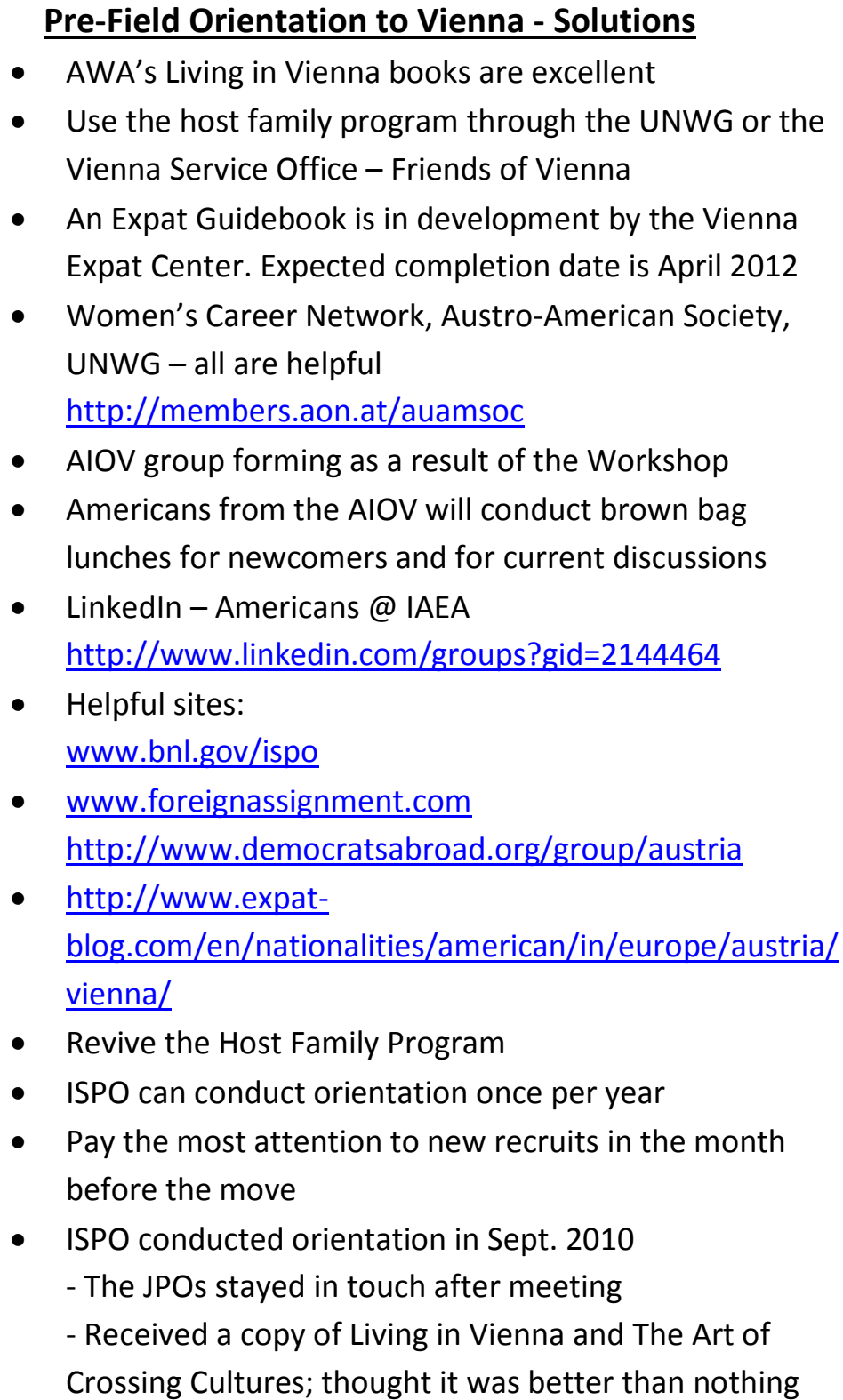 \\
\hline
\end{tabular}




\begin{tabular}{|c|c|}
\hline ISSUES FACING U.S. CITIZENS: & ASSISTANCE: \\
\hline $\begin{array}{l}\text { Singles } \\
\text { - HR introduction package is too } \\
\text { family-oriented. It doesn't have } \\
\text { single people in mind. Tailor the } \\
\text { packages more-age group, } \\
\text { demographic } \\
\text { - General lack of info geared to singles } \\
\text { - How do singles get to meet other } \\
\text { single Americans already living in } \\
\text { Vienna? } \\
\text { - Lonely/no one to vent to } \\
\text { Need an emergency contact person } \\
\text { in Vienna } \\
\text { Where to live-what area of city is } \\
\text { best for singles } \\
\text { Taking time off to get situated/take } \\
\text { care of cable, phone, maintenance } \\
\text { Lone Amcit in Austrian clubs/socials } \\
\text { IAEA Safeguards does more for JPOs } \\
\text { and CFEs than other I/Os and other } \\
\text { IAEA departments }\end{array}$ & $\begin{array}{l}\text { - Singles } \\
\text { - } \text { Vienna Host person specifically for Singles } \\
\text { - } \text { IAEA Newsletter (similar to one done by the interns) } \\
\text { - } \text { Facebook page with info about singles events } \\
\text { - Internations- social network for expats from around the } \\
\text { - } \text { - } \text { Create an interest group/chat room for messages } \\
\text { - } \text { Reach out to co-workers } \\
\text { - Point of contact within your section/ } \\
\text { - Jivision/department } \\
\text { - Take part in events that are taking place all over } \\
\text { - Visit the Vienna Expat Center for social events } \\
\text { - Enlist children of US families that are looking for work to } \\
\text { - } \text { watch pets, wait for cable, etc. } \\
\text { - Make contacts with administrative staff who are local } \\
\text { and know how to work the bureaucracy } \\
\text { more accessible }\end{array}$ \\
\hline $\begin{array}{ll}\text { Retirement } \\
\text { - } \\
\text { Options for retirement for long time } \\
\text { - } \quad \text { Stay in Austria } \\
\text { - } & \text { Return to US } \\
\text { - } & \text { Rumor about extending retirement } \\
\text { - } & \text { age at IAEA/UN } \\
\text { Understanding how bureaucracy } \\
\text { works in Austria }\end{array}$ & $\begin{array}{l}\text { Retirement } \\
\text { - } \quad \text { Volunteer as a Host for newcomers } \\
\text { - Ask if the UN/VIC will provide guidance and assistance } \\
\text { - for retiring in Austria } \\
\text { - Contact attorney from the AIOV Workshop: Elmar } \\
\text { Drabek at Dorda, Brugger, Jordis; elmar.drabek@dbj.at }\end{array}$ \\
\hline $\begin{array}{l}\text { Shipping } \\
\text { - Shipping/Customs/Immigration } \\
\text { Information distributed should } \\
\text { be more reliable }\end{array}$ & $\begin{array}{l}\text { Shipping } \\
\text { Would IAEA consider an option of Do-It-Yourself for } \\
\text { shipment? }\end{array}$ \\
\hline$\frac{\text { Transition }}{\text { Prior to Arrival }}$ & $\frac{\text { Transition - Solutions }}{\text { Prior to Arrival }}$ \\
\hline
\end{tabular}




\begin{tabular}{|c|c|}
\hline ISSUES FACING U.S. CITIZENS: & ASSISTANCE: \\
\hline $\begin{array}{l}\text { - How to relocate to Vienna } \\
\text { - Not enough info on importation } \\
\text { of pets } \\
\text { - No insurance coverage between } \\
\text { employers or during transition to } \\
\text { Vienna } \\
\text { After Arrival } \\
\text { New arrivals should be } \\
\text { interviewed four to six months } \\
\text { after arrival to identify things they } \\
\text { learned the hard way }\end{array}$ & 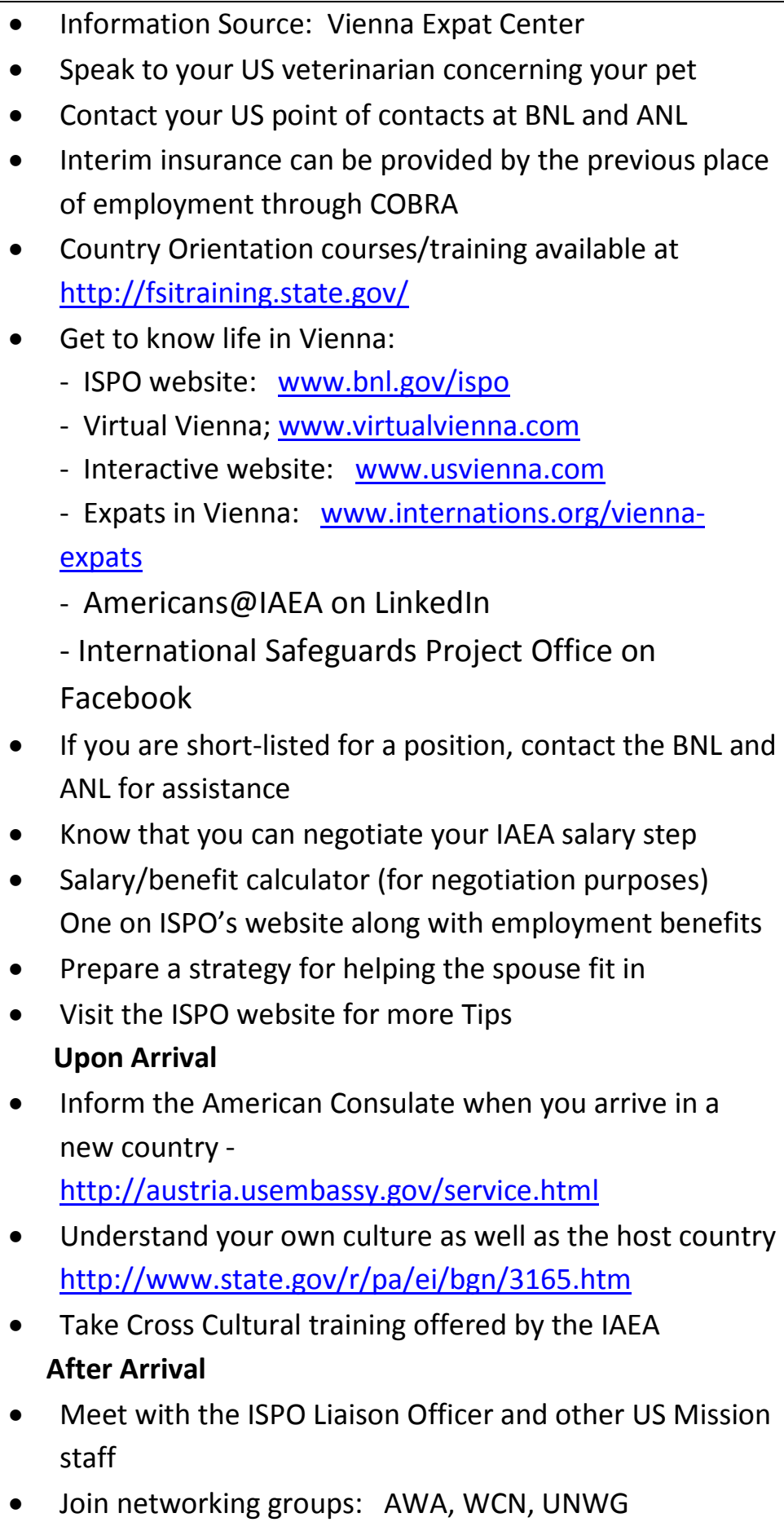 \\
\hline $\begin{array}{l}\text { Medical } \\
\text { - Need doctor recommendations } \\
\text { - Don't trust VIC medical lists }\end{array}$ & $\begin{array}{l}\text { Medical } \\
\text { Visit the U.S. Embassy website at } \\
\text { http://austria.usembassy.gov/med.html for a list of }\end{array}$ \\
\hline
\end{tabular}




\begin{tabular}{|c|c|}
\hline ISSUES FACII & ASSIS \\
\hline $\begin{array}{l}\text { completely } \\
\text { - The English-speaking doctors are } \\
\text { not necessarily the best } \\
\text { - Medical facility information is } \\
\text { needed }\end{array}$ & $\begin{array}{l}\text { medical services, etc. in Vienna } \\
\text { - Visit the City of Vienna website for a list of doctors; } \\
\text { http://www2.aekwien.at/997E.py } \\
\text { - Visit the VIC Medical Office }\end{array}$ \\
\hline $\begin{array}{l}\text { Repatriation: } \\
\text { - } \text { Reverse Culture Shock } \\
\text { Manic attack in the Super Wal- } \\
\text { - High prices of wine, food, etc. } \\
\text { - } \text { Repatriation regarding home and } \\
\text { work needs appropriate } \\
\text { consideration } \\
\text { - Need help finding the next job - } \\
\text { re-entry employment/ counseling } \\
\text { service } \\
\text { If you're not from a National Lab, it } \\
\text { is not easy to find a job in the US. }\end{array}$ & $\begin{array}{l}\text { Repatriation - Solutions } \\
\text { - } \text { Reverse culture shock is normal ; be aware and plan } \\
\text { - } \text { Can take time to adapt to home country } \\
\text { - } \text { Don't take yourself too seriously } \\
\text { - Gather employment contacts } \\
\text { - Identify employment opportunities } \\
\text { - Commercial nuclear industry } \\
\text { - US government } \\
\text { - Jistribute resumes } \\
\text { - Usin professional organizations } \\
\text { - Contact ISPO for assistance and recommendations }\end{array}$ \\
\hline $\begin{array}{l}\text { Miscellaneous } \\
\text { - } \quad \text { College age children need an } \\
\text { international student ID card to get } \\
\text { discounts in Vienna } \\
\text { - } \quad \text { Language barrier } \\
\text { - Vienna can be expensive for families } \\
\text { - Initial cash flow problems (Taxes, } \\
\text { - } \text { rent, school) } \\
\text { - Sank fees } \\
\text { - Inconial adjustments } \\
\text { Vienna stores } \\
\text { - closed on Sundays, limited hours } \\
\text { Dollar/Euro rate: how will this affect } \\
\text { me } \\
\text { How does ISPO find out when }\end{array}$ & $\begin{array}{l}\text { Miscellaneous - Solutions } \\
\text { - Continue periodic gatherings with new and seasoned } \\
\text { employees; stay positive } \\
\text { - } \text { Suggestion: Subsidy for cultural activities } \\
\text { Overcome the language barrier by taking German } \\
\text { classes immediately; not necessarily at the UN } \\
\text { - Watch German-language TV } \\
\text { - Explore the city using the excellent public transportation } \\
\text { - } \text { and the Hop-On-Hop-Off tourist bus } \\
\text { - } \text { IAEA HR provides US Mission contact info to new arrivals } \\
\text { - Services for viewing US TV } \\
\text { - } \text { - Thingbox of the experience as a long travel trip } \\
\text { - Don't make any rash decisions for } 6 \text { months after arrival } \\
\text { - Be proactive- research districts in the city }\end{array}$ \\
\hline
\end{tabular}




\begin{tabular}{|c|c|}
\hline ISSUES FACING U.S. CITIZENS: & ASSISTANCE: \\
\hline $\begin{array}{l}\text { - Watching US TV is not that easy } \\
\text { - } \quad \text { Certain consumer items only } \\
\text { available seasonally } \\
\text { It is easy to get stuck in the UN } \\
\text { bubble and never live in Vienna; } \\
\text { meet Austrians } \\
\text { - Americans get together to } \\
\text { vent/complain } \\
\text { - It encourages you to look for the } \\
\text { negative } \\
\text { - It takes time to get used to the new } \\
\text { environment } \\
\text { - Must have realistic expectations } \\
\text { Driving course needed }\end{array}$ & $\begin{array}{l}\text { - Keep trying to meet new people since people come and } \\
\text { go } \\
\text { - Understand the pros and cons, and decide when } \\
\text { the rewards no longer outweigh the negatives }\end{array}$ \\
\hline $\begin{array}{l}\text { Personal } \\
\text { - Initial reaction is to circle the } \\
\text { wagons and isolate yourself } \\
\text { - One never really feels settled } \\
\text { - Short contracts leave little time to } \\
\text { plan } \\
\text { - Lose touch with family and friends } \\
\text { - Everyone in home state has } \\
\text { - } \text { moved ahead } \\
\text { - Isolation; loneliness } \\
\text { - Concern over contract extension } \\
\text { (JPO, CFE) } \\
\text { - What is the career path? }\end{array}$ & $\begin{array}{l}\text { Activities } \\
\text { - Vienna is a family-friendly city } \\
\text { - Travel throughout Europe is easy from Vienna } \\
\text { - Many activities for young children/families } \\
\text { - Social activities are abundant } \\
\text { - Make some Austrian friends } \\
\text { - Austrians will help you learn new games/sports } \\
\text { - Recreation at the VIC } \\
\text { - Movie night - English Cinemas } \\
\text { - Expat Center - clubs, cocktail parties } \\
\text { - Arrange welcome dinners } \\
\text { - Join Austrian Clubs/Organizations: ex., the Austro- } \\
\text { - American Society } \\
\text { - } \text { Intenna Service Office - located in the Vienna } \\
\text { Friends of Vienna - UNWG }\end{array}$ \\
\hline
\end{tabular}


APPENDIX E. Registration/Attendance List

\begin{tabular}{|c|c|c|c|c|}
\hline TIILE & FNAME & LNAME & AFFIUATION & Attended \\
\hline Mrs. & Emebet (Amy) & Amenu-Zotter & UNVIE & \\
\hline Mr. & Steven & Amundson & IAEA & \\
\hline Ms. & Jeanne & Anderer & IAEA & \\
\hline Mr. & Adam & Bacheller & IAEA & \\
\hline \multirow[t]{2}{*}{ Mrs. } & Noel & Bacheller & IAEA - Spouse & \\
\hline & Brian & Bales & IAEA & \\
\hline Dr. & Randy & Beatty & IAEA & \\
\hline Ms. & Claire & Beauparlant & IAEA - Spouse & \\
\hline Mr. & Phil & Beauparlant & IAEA & \\
\hline \multirow[t]{5}{*}{ Dr. } & David & Beddingfield & IAEA & \\
\hline & Lori & Birkholz & IAEA - Spouse & \\
\hline & Carmen & Borsa & Spouse & \\
\hline & Friedrich & Bruckner & Vienna Expat Center & \\
\hline & Kettly & Calixte Fielhauer & IAEA & \\
\hline Dr. & Alisa & Carrigan & IAEA & \\
\hline Mr. & Steve & Cathersal & None & \\
\hline Ms. & Kaisa & Clark & IAEA & \\
\hline Ms. & Tanya & Collins & BNL & \\
\hline Mr. & Brady & Collins & University of Illinois & \\
\hline \multirow[t]{4}{*}{ Ms. } & Paula & Cook & IAEA & \\
\hline & Nathan & Cooper & UNVIE & \\
\hline & Clinton & Cowan & IAEA & \\
\hline & L. Marie & Cronholm & IAEA & \\
\hline Ms. & Martina & Darnell & UNODC & \\
\hline Ms. & Margaret & Davidson & IAEA & \\
\hline Mr. & Helly & Diaz Marcano & IAEA & \\
\hline Mr. & Srdjan & Djokovic & IAEA & \\
\hline Ms. & Kathleen & Donoghue & IAEA & \\
\hline Mr. & Gregory & Dupuy & IAEA & \\
\hline Mrs. & Melanie & Feitzinger & IAEA & \\
\hline Ms. & Yana & Feldman & IAEA & \\
\hline Mr. & Scott & Fertig & IAEA & \\
\hline \multirow[t]{2}{*}{ Ms. } & Barbara & Figiel & IAEA & \\
\hline & Diane & Fischer & IAEA & \\
\hline Ms. & Kate & Fitzpatrick & US Senate & \\
\hline Ms. & Marcy & Fowler & IAEA & No \\
\hline Ms. & Zoe & Gastelum & IAEA & \\
\hline Mr. & michael & gates & Richard Lewis Communications & \\
\hline Mr. & Chris & Gazze & IAEA & \\
\hline Ms. & Maria Samantha & Gehring & IAEA & \\
\hline Mr. & Lawrence & Gohar & IAEA & \\
\hline Mrs. & Mary & Gohar & IAEA - Spouse & \\
\hline Ms. & Sasa & Gorisek & IAEA & \\
\hline Ms. & lydia & goutas & speaker & \\
\hline \multirow[t]{3}{*}{ Mr. } & Vinson & Granando & IAEA & \\
\hline & Mary & Hagan & Partner & \\
\hline & Sunaree & Hamilton & ANL & \\
\hline Dr. & Mark & HARPER & IAEA & \\
\hline Mrs. & Laura & Harper & IAEA & \\
\hline
\end{tabular}




\begin{tabular}{|c|c|c|c|c|}
\hline TIILE & FNAME & LNAME & AFFIUATION & Attended \\
\hline Mrs. & Meral & Harris & IAEA-Safeguards/SGTS & \\
\hline Mr. & Charles & Havekost & IAEA & \\
\hline Mrs. & Eva & Havekost & IAEA - Spouse & \\
\hline \multirow[t]{2}{*}{ Prof. } & Curtiss & Hunt & IAEA & \\
\hline & Gabi & Hurt & UNVIE & \\
\hline Ms. & Jenifer & Jones & IAEA - Spouse & \\
\hline \multirow[t]{3}{*}{ Mr. } & Peter & Kaiser & IAEA & \\
\hline & Masood & KARIMIPOUR & UNODC & \\
\hline & Thomas & Killeen & IAEA & No \\
\hline Ms. & Holli & Klein & IAEA & \\
\hline Mr. & Christopher & Klemm & U.S. Department of State & \\
\hline Dr. & Snezana & Konecni & IAEA & \\
\hline Ms. & Sinsze & Koo & IAEA & \\
\hline Mr. & Donald & Kovacic & IAEA & \\
\hline Mrs. & Kim & Kovacic & IAEA & \\
\hline Mr. & Nicholas & Krakker & UN & \\
\hline \multirow[t]{2}{*}{ Mrs. } & Rebecca & Kunz & IAEA & \\
\hline & Mark & Laughter & IAEA & No \\
\hline Mr. & Anthony & Lavietes & IAEA & No \\
\hline Ms. & Valerie & Lewis & IAEA & \\
\hline Dr. & Shelly & Li & IAEA & \\
\hline Ms. & Courtney & Linley & СТВто & \\
\hline Mr. & Dunbar & Lockwood & DOE/NNSA HQ & \\
\hline Ms. & Paola & Luchi & ANL & \\
\hline Ms. & Adriana & Lukovac Djokovic & IAEA - Spouse & \\
\hline Mr. & Eduardo & LURASCHI & IAEA & \\
\hline Ms. & Adrea & Mach & IRENA & \\
\hline Ms. & Jennifer & Marek & IAEA & \\
\hline Mrs. & Jo Dee & Martinez & IAEA - Spouse & \\
\hline Mr. & Christopher & Martinez & IAEA & \\
\hline Mrs. & Donna & Mascarenhas & IAEA - Spouse & \\
\hline Dr. & Nicholas & Mascarenhas & IAEA & \\
\hline Ms. & Carrie & Mathews & IAEA & \\
\hline \multirow[t]{2}{*}{ Ms. } & Elizabeth & Mattfeld & UNODC & \\
\hline & Steve & McNulty & IAEA & \\
\hline Ms. & Catherine & Monzel & IAEA & \\
\hline Mr. & Bruce & Moran & IAEA & \\
\hline Mr. & Keith & Morgan & IAEA & \\
\hline Mrs. & Natalie & Morgan & IAEA - Spouse & \\
\hline Mr. & Jesse & Murray & IAEA & \\
\hline Ms. & Traci & Newton & IAEA & \\
\hline Mrs. & Heather & Nordquist & IAEA & No \\
\hline Mr. & Terrence & Nordquist & IAEA - Spouse & No \\
\hline Ms. & Donna & Occhiogrosso & BNL & \\
\hline Mrs. & Amber & Osmancevic-Zhang & UNODC & \\
\hline Ms. & Cathy & Pasterczyk & IAEA & No \\
\hline \multirow[t]{2}{*}{ Mr. } & Aaron & Peacock & IAEA & \\
\hline & James & Peirce & IAEA & \\
\hline
\end{tabular}




\begin{tabular}{|c|c|c|c|c|}
\hline TIILE & FNAME & LNAME & AFFIUATION & Attended \\
\hline & Susan & Pepper & BNL & \\
\hline & Jon & Phillips & PNNL & \\
\hline Mr. & Joseph & Podles & IAEA - Spouse & \\
\hline Mrs. & Jenny & Polich & & \\
\hline Mr. & Paul & Polich & СТВTO & \\
\hline \multirow[t]{2}{*}{ Dr. } & harald & poths & IAEA - Spouse & \\
\hline & Allen & Prattis & IAEA & \\
\hline \multirow[t]{2}{*}{ Mr. } & Al & Queirolo & UNVIE & \\
\hline & Francesco & Queirolo & IAEA & \\
\hline Ms. & Michele & Rabatin & BNL & \\
\hline Mr. & Lee & ReFalo & IAEA & No \\
\hline Mr. & jim & regula & IAEA & No \\
\hline Mr. & Jorge Eduardo & Rios & UNODC & \\
\hline Mr. & Frederick & Robinson & Architect / Spouse & \\
\hline Mrs. & Roxanne & Roybal de Diaz & Spouse & \\
\hline Ms. & Deborah & Rudolph & DOS & \\
\hline Mr. & Joshua & Rutkowski & IAEA & \\
\hline Mr. & Matthew & Seitz & UNODC & \\
\hline Mr. & David & Smith & IAEA & \\
\hline Mr. & James & Sprinkle & IAEA & \\
\hline Mrs. & Karina & Staub Pellichi & IAEA - Spouse & \\
\hline \multirow[t]{2}{*}{ Ms. } & Rebecca & stevens & IAEA & \\
\hline & Ingrid & Sweeney & IAEA - Spouse & \\
\hline Ms. & Andrea & Tantillo & IAEA & \\
\hline Mrs. & Lisa & Villard & IAEA & \\
\hline Mr. & Todd & Vincent & CTBTO Preparatory Commission & \\
\hline Ms. & Catherine & Wells & IAEA - Spouse & \\
\hline Mr. & Peter & Wells & IAEA & \\
\hline Ms. & Jane & Welsh & partner works at IAEA & \\
\hline Mrs. & Meredith & Wilson & IAEA - Spouse & \\
\hline Ms. & Susan & Wolfe & MIIS & \\
\hline Mrs. & Ashley & Wroten & UNVIE & \\
\hline Ms. & Hanano & Yamada & IAEA & \\
\hline \multirow[t]{2}{*}{ Mr. } & Jack & Zhang-Osmancevic & UNODC & \\
\hline & Jill & Zubarev & UNVIE & \\
\hline
\end{tabular}


APPENDIX F. Dunbar Lockwood's Presentation, "DOE/NNSA Perspective: NGSI, Recruitment, and Repatriation"

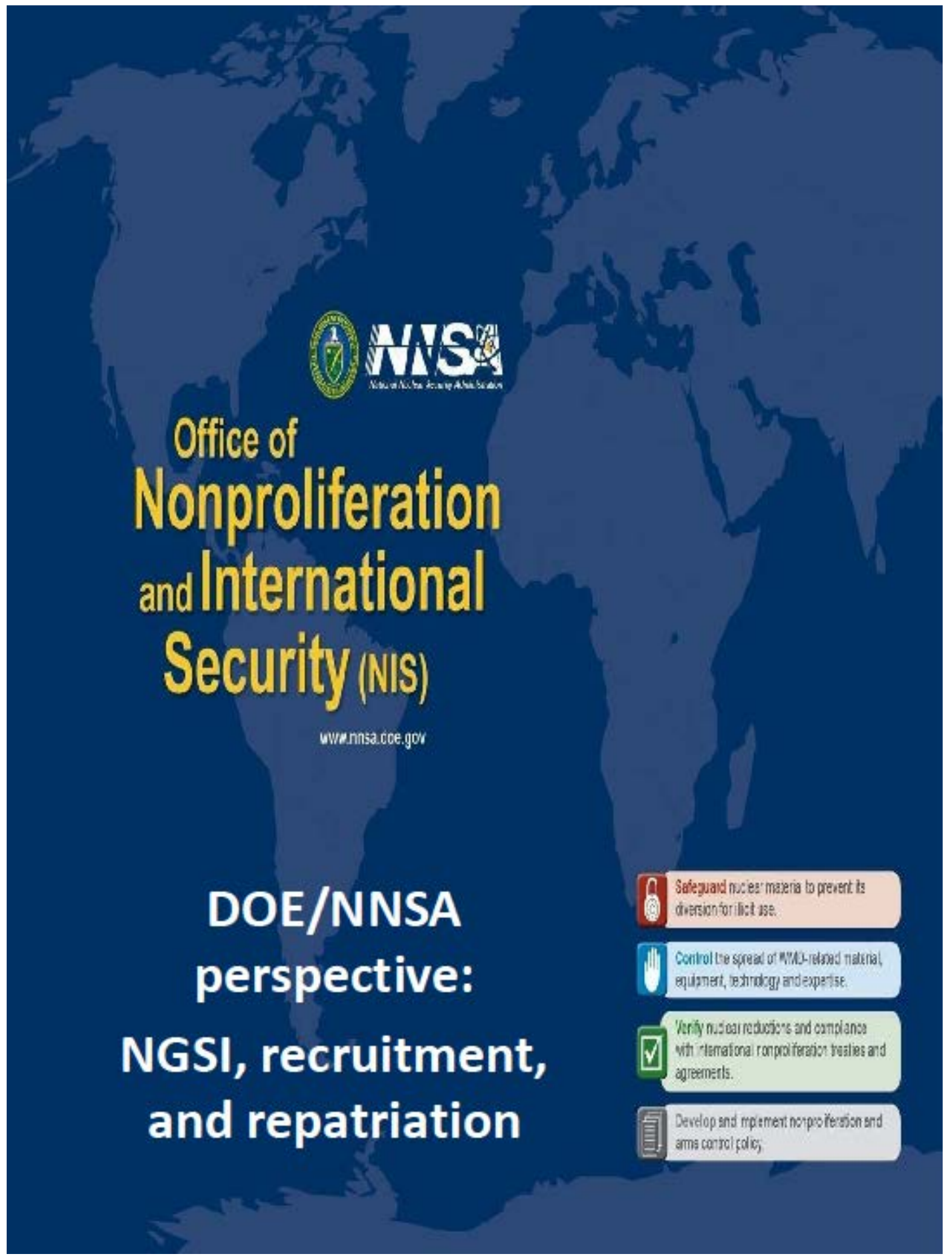


 \\ Presentation Overview

- NNSA's Next Generation Safeguards Initiative (NGSI)

- IAEA experience within DOE's National Laboratory complex

- Recruitment: United States $\rightarrow$ Vienna

- Repatriation: Vienna $\rightarrow$ United States

- Opportunities for JPOs and new safeguards professionals 
A robust, multi-year program to develop the policies, concepts, technologies, expertise, and international safeguards infrastructure necessary to strengthen and sustain the international safeguards system as it evolves to meet new challenges over the next 25 years .

The initiative consists of five strategic subprograms:

- Policies Development \& Outreach

- Concepts and Approaches

- Technology Development

- Human Capital Development

- International Engagement
"The United States has called for added resources and authorities for the IAEA." President Obama in Vienna, September 2010

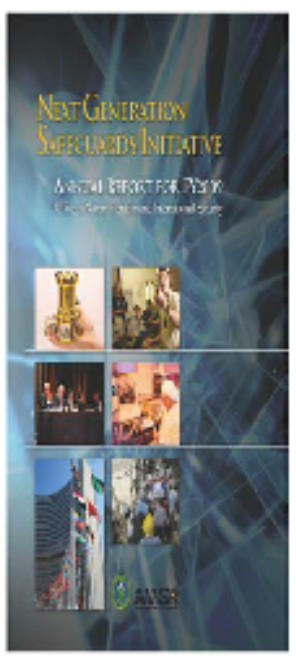


- Revitalizing and expanding the international safeguards human capital base in the United States by attracting, educating, training, and retaining a new generation of talent

- Recruiting high quality candidates for positions in the IAEA's Safeguards Department

- Encouraging the transition of former IAEA staff to positions in the U.S. National Laboratories 
Office of

Nonprolfferation

and International

\section{DOE National Laboratories:
Staff with IAEA experience \\ DOE National Laboratories:
Staff with IAEA experience

Security (NIS)

\section{Attrition of 2009 International}

Safeguards Specialist Lab Staff with

IAEA Experience

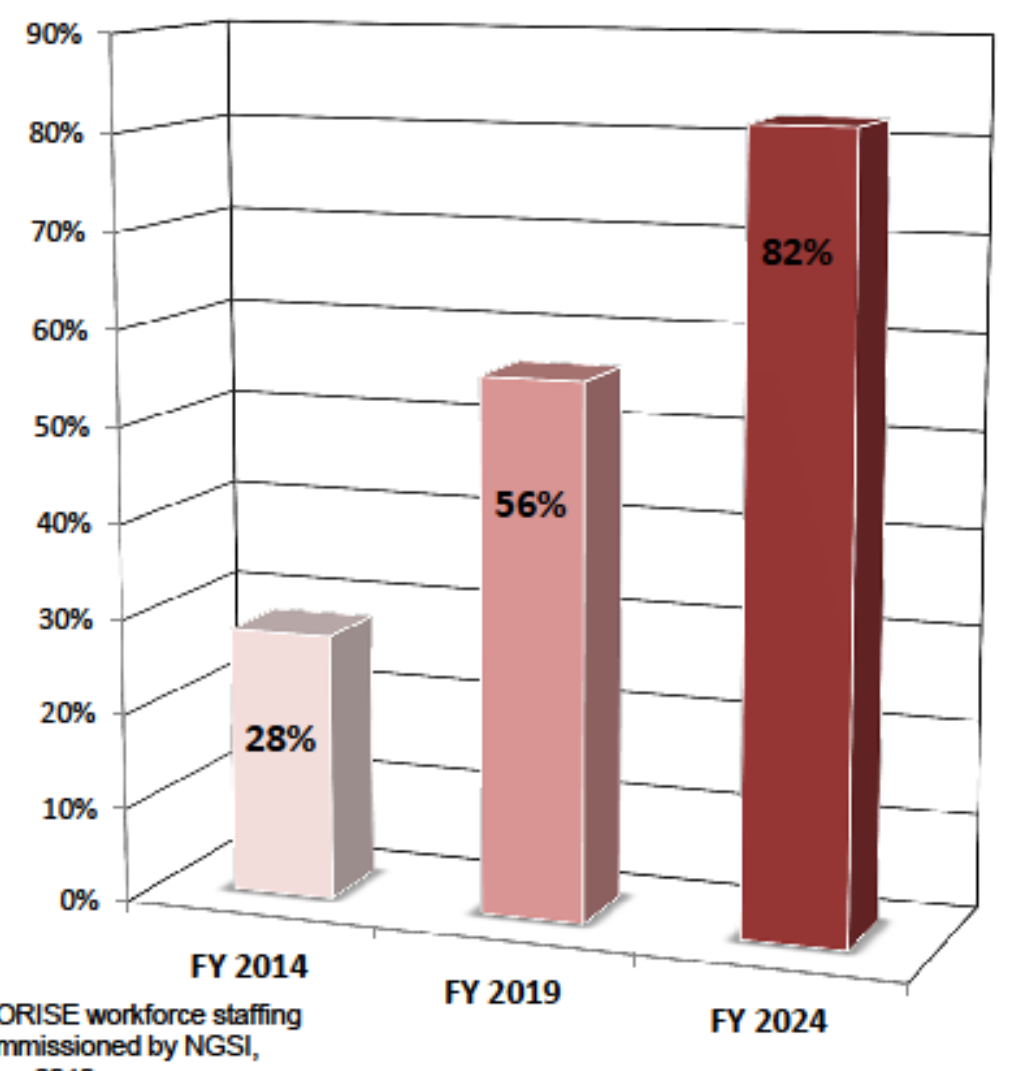

Source: ORISE workforce staifin

study commissiomber 2010 


\section{(1) NHS}

Off Ce of

Nonprolfieration

and International Security (NIS)

\section{DOE National Laboratories:}

\section{Labs with safeguards expertise}

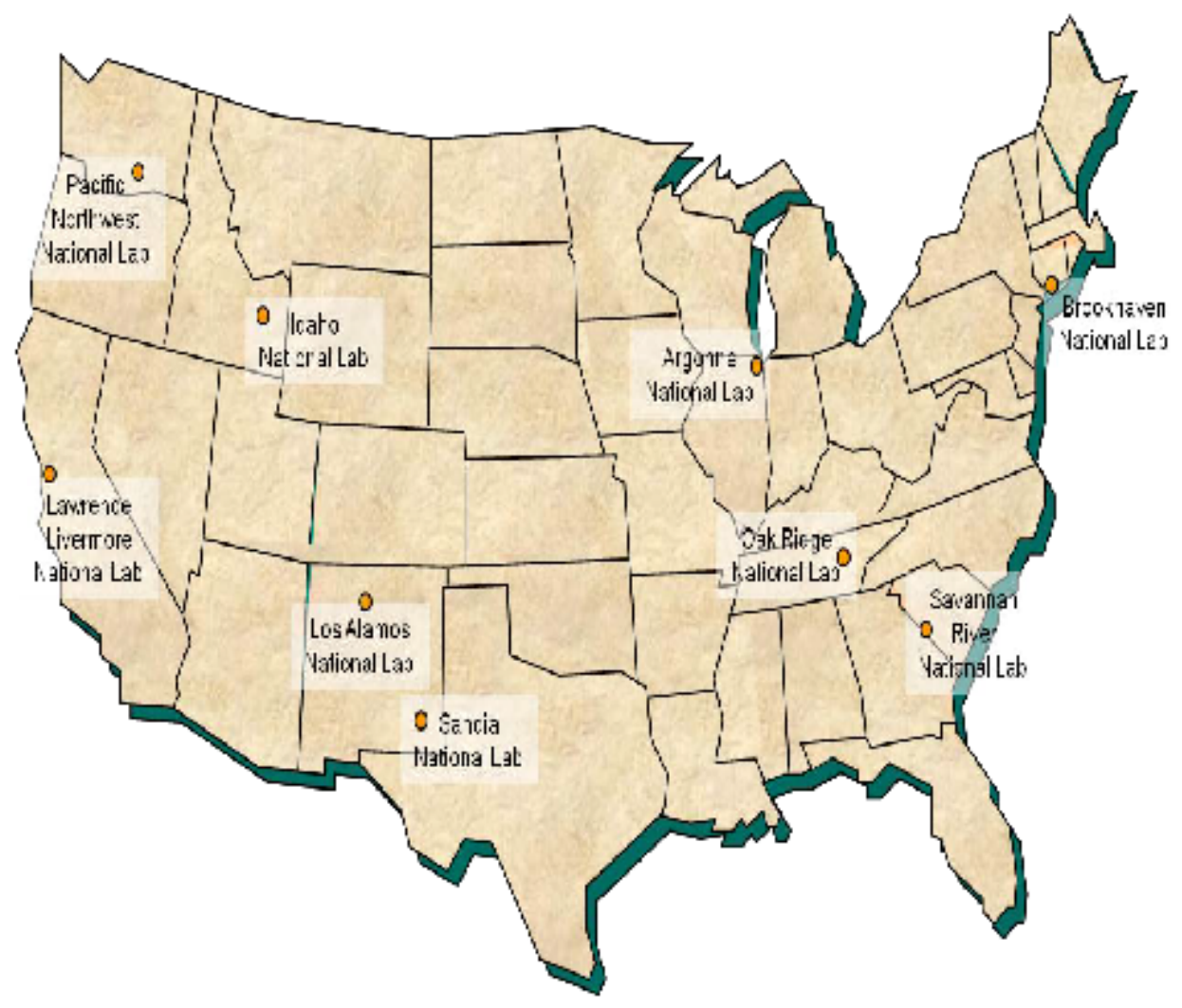


Nonproliferation

and International

\section{Recruitment}

\section{United States $\rightarrow$ Vienna}

Security iNIs)

Previously supporting NGSI work

- David Beddingfield

- Marie Cronholm

- Greg Dupuy

- Diane Fischer

- Zoe Gastelum

- Sinsze Koo

- Mark Laughter

- Carrie Mathews

- Adam Shephard

- Eric Smith

- Jim Sprinkle

- Rebecca Stevens
SGTS

JPO

JPO

SGIM

JPO

JPO

Ops C

SGCP

JPO

SGTS

SGCP

SGCP
LANL

NNSA/PNNL

NNSA/BNL

ORNL

PNNL

ORNL/SRNL

ORNL

PNNL

ORNL

PNNL

LANL

LANL 


\section{Repatriation Vienna $\rightarrow$ United States

Former IAEA staff now supporting NGSI work at the

\section{U.S. National Labs}

- George Anzelon

SGIM

LLNL

- Brian Boyer

SGOC/SGCP

- Michael Curtis

Ops C

BNL/LANL

- Casey Durst

SGOA/SGOC/SGDDG

PNNL

- Mike Ehinger

SGOA

INL

- Les Fishbone

SGCP

ORNL

- Jim Garner

JPO

BNL

- Dave Hanks

SGOC

- Rich Hooper

SGCP

ORNL

- Phil Hypes

SGTS

PNNL

- Shirley Johnson

SGOA/SGOB/SGOC

JPO

intern, MTPI

SGCP

LANL

- Patrick Lynch

- Sarah Poe

- Michael Rosenthal

SGTS

SRNL/NRC

- Mark Schanfein

SGIM

PNNL/BNL

ORNL

BNL

BNL

LANL/INL

- Rick Wallace

LANL 
Offce of

Nonprolfieration

and International

Security NIS)

\section{USG Agencies that value IAEA experience 0}

- Nuclear Regulatory Commission (NRC)

- U.S. Department of State
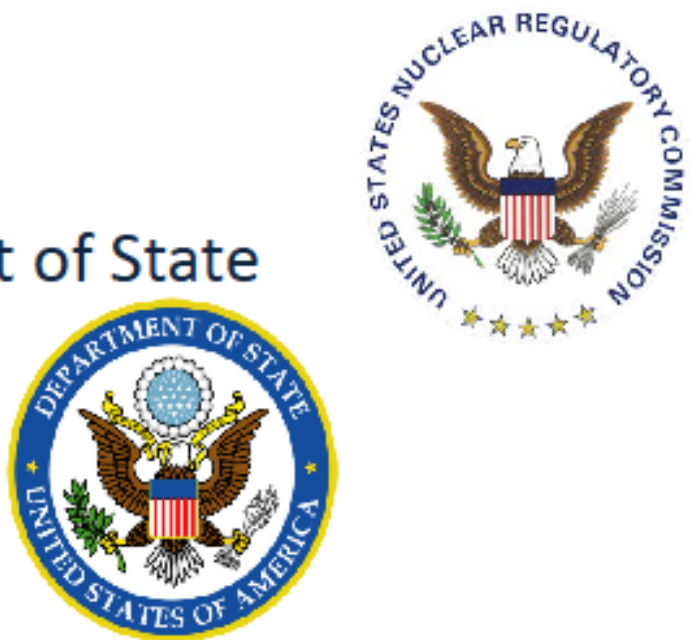

- U.S. Department of Energy

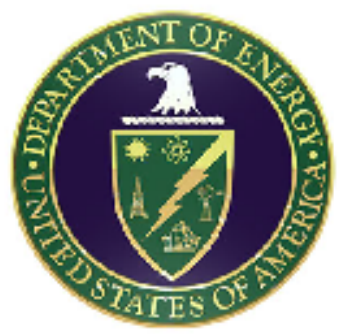


Offce of

Nonproliferation and International Security (NIS)

\section{Opportunities for JPOs and} new safeguards professionals

- Next Generation Safeguards Professional Network

- a resource for permanent safeguards staff new to the field

www.ngspn.org

- Nuclear Nonproliferation and International Safeguards Graduate Fellowship

- 2-4 years of tuition support + stipend for technical PhD candidates

http://ngfp.pnnl.gov

- Nonproliferation Graduate Fellowship Program

- one year placement at NNSA for recent university graduates

http://scuref.org/nnis-overview

- NNSA Future Leaders

- entry-level program into NNSA as Federal staff

http://nnsa.energy.gov/futureleaders 
- Clemson University

- University of California, Berkeley

- University of Florida

- Georgia Institute of Technology

- University of Illinois

- Massachusetts Institute of Technology

- University of Michigan

- University of Missouri

- North Carolina State University

- Oregon State University

- University of Tennessee

- University of Texas

- Texas A\&M University 
Nonproliferation

and International

\title{
Contact Information \\ $\sqrt{8}$

Security (NIS)

Dunbar Lockwood

Dunbar.Lockwood@nnsa.doe.gov

+1-202-586-6951

\author{
Melissa Scholz \\ Melissa.Scholz@nnsa.doe.gov \\ +1-202-586-4397
}

